\title{
Біомеханіка просторової організації тіла людини: теоретичні та практичні аспекти
}

\section{Віталій Кашуба, Наталія Гончарова, Наталія Носова}

Національний університет фізичного виховання і спорту України, Київ, Україна

Анотація. У статті на основі аналізу науково-методичної літератури визначено суть поняття «просторова організація тіла людини» та його зміну в історичному аспекті. Розглянуто суть фрормування зовнішнього прояву тіла людини під впливом генетично обумовленої програми індивідуального розвитку. Систематизовано наукове знання про зміст тілесної культури, еталонів краси людського тіла, порушень його просторової організації. Окреслено здобутки науковців Національного університету фрізичного виховання і спорту України у вивченні особливостей формування просторової організації тіла людини. Мета. На основі теоретичного аналізу і власних експериментальних досліджень обгрунтувати та розробити концепцію формування просторової організації тіла людини у процесі занять фізичними вправами для підвищення її здоров'ясормуючої та здоров'язберігаючої спрямованості. Методи. Теоретичні, соціологічні, антропометричні, біомеханічні, педагогічні, кваліметрії та математичної статистики. Результати. Запропоновано основи концепції формування просторової організації тіла людини, що включає підходи загальнонаукового та конкретнонаукового рівня, термінологічний апарат, інструментарій оцінювання та програмні продукти інформаційного супроводу моніторингу просторової організації тіла людини в процесі занять фізичними вправами, здоров'яформуючі та здоров'якорегуючі технології. Здоров'яформуючі технології спрямовані на формування просторової організації тіла людини, покращення рівня фрізичного стану, рухової активності, мотивації до систематичних занять фрізичними вправами. Впроваджуються протягом трьох етапів, містять такі компоненти: адаптаційний, операційно-діяльнісний, аксіологічний, гносіологічний, контрольний. Серед провідних засобів здоров'яформуючої діяльності визначено засоби активного туризму. Здоров'якорегуючі технології реалізовані у вигляді технології профрілактики та корекції фуннціональних порушень опорно-рухового апарату дітей старшого дошкільного віку засобами фрізичної реабілітації в умовах закладів дошкільної освіти, що охоплює: мету, завдання, принципи, має компонентну структуру та три етапи реалізації. Реалізується через комплекс заходів різної спрямованості.

Ключові слова: просторова організація тіла, здоров'яформуючі технології, здоров'якорегуючі технології, особи різного віку, концепція, методологія.

\section{Vitalii Kashuba, Natalia Honcharova, Natalia Nosova}

\section{BIOMECHANICS OF HUMAN BODY SPATIAL ORGANIZATION: THEORETICAL AND PRACTICAL ASPECTS}

Abstract. The article, based on the analysis of scientific and methodological literature, defines the essence of the concept of «human body spatial organization» and its change in the historical aspect. The essence of the formation of human body external manifestation under the influence of a genetically determined program of individual development is considered. Scientific knowledge on the content of bodily culture, standards of the human body beauty, violations of its spatial organization is systematized. The achievements of scientists of the National University of Physical Education and Sport of Ukraine in studying the peculiarities of the formation of the human body spatial organization are outlined. Objective. On the basis of theoretical analysis and own experimental researches to substantiate and develop the concept of formation of the human body spatial organization in the course of practicing physical exercises to increase its health-forming and health-preserving orientation. Methods. Theoretical, sociological, anthropometric, biomechanical, pedagogical, qualimetry and mathematical statistics. Results. The basics of the concept of the human body spatial organization formation, which includes approaches of general and specific scientific level, terminology, assessment tools and software products for monitoring the spatial organization of the human body during exercise execution, health-forming and health-correcting technologies. Health-forming technologies are aimed at the formation of the human body spatial organization, improvement of the level of physical condition, motor activity, motivation for regular exercise. They are implemented during three stages and contain the following components: adaptive, operational, axiological, epistemological, control. Among the key means of health-promoting

Kashuba V, Honcharova N, Nosova N Biomechanics of human body spatial organization: theoretical and practical aspects. Theory and Methods of Physical education and sports. 2020; 2: 67-84

DOI: 10.32652/tmfvs.2020.2.67-84
Кашуба В, Гончарова Н, Носова Н Біомеханіка просторової організації тіла людини: теоретичні та практичні аспекти. Теорія і методика фрізичного виховання і спорту. 2020; 2: 67-84 DOl: 10.32652/tmfvs.2020.2.67-84
Вступ. Людина знає світ настільки, наскільки діяла в ньому - подумки і практично. Вона реорганізовує зовнішній світ в термінах особистості, яка творить смисли, будує свої дії у термінах індивідуально-семантичного тезауруса. Тезаурус творчої особистості являє собою смислову організованість діяльнісної свідомості - сукупність понять, категорій, тілесного досвіду, ресрлексивних знань, які використовуються в різних ситуаціях діяльності та спілкування для досягнення особистісно-значущого результату [8]. Потік живої людської свідомості являє собою семантично організований нелінійний процес, в якому смисловий соціокультурний зміст рухових дій (норми, установки, цінності, прийняті в даній культурі) тісніше пов'язаний з їхніми інформаційними та енергетичними характеристиками, заданими від природи. Тому біомеханічна реальність незмінно постає перед нами трансформованою (ментально реорганізованою) нашими когнітивними здібностями, суб'єктною психофрізикою, світоглядними позиціями, фрільтрами сприйняття, «ментальним програмуванням», соціокультурним контекстом [8].

Біологічна система організму людини, взаємодіючи 3 навколишнім середовищем, постійно змінюється в часі і просторі та визначається величинами своїх змінних характеристик [10-17, 34-39]. Зовнішній вигляд людського тіла спочатку заданий генетичною інфрормацією, яка передалася від батьків, і максимально індивідуальний. Зовнішність - це найперша і очевидна ознака, що індивідуалізує людину. Симетричність біомеханічної конструкції рухової системи проявляється завдяки тому, що саме такий розподіл мас у просторі дозволяє людині більш ефективно управляти гравітаційними взаємодіями під час переміщення тіла [10-17, 34-39]. Найважливішим поняттям, пов'язаним з орієнтацією тіла людини в просторі і з усією сукупністю рухових дій, є про- 
activities are the means of active tourism. Health-correcting technologies are implemented in the form of technology for prevention and correction of functional disorders of the musculoskeletal system of senior preschool children by means of physical rehabilitation in preschool establishments, which includes: task, objective, principles, has a component structure and three stages of implementation. They are implemented through a set of measures of different orientation.

Keywords: body spatial organization, health-forming technologies, health-correcting technologies, persons of different ages, concept, methodology.

сторова організація біоланок їі тіла. На сучасному рівні знань просторову організацію тіла розуміють як єдність морфологічної та функціональної організації людини, що відображається в її «габітусі» $[26,27]$.

Просторова організація тіла характеризується біогеометричним профілем постави, формою статури, пропорціями і типом конституції, топографією сил різних м'язових груп, використовується як характеристика фрізичного розвитку здоров'я людини та як поняття, що дозволяє пояснити, яким чином людина не тільки сприймає простір, а й реалізує свій руховий потенціал [10-17, 34-39]. Просторова організація тіла відображає уявлення людини про власне тіло і відіграє помітну роль у формуванні власного іміджу в очах оточуючих [26].

Різноманіття підходів до інтерпретації поняття «тіло» проявляється як на рівні буденної, масової свідомості та похідних від неї практик, так і в рамках спеціалізованих, професійних видів діяльності, в тому числі на рівні конкретно-наукового і фрілософського пізнання. У фрілософрському енциклопедичному словнику тіло визначається як: 1) назва матеріальної протяжної речі як чогось об'єктивно фрізичного; 2) неточна назва матеріального носія життя організму, зокрема організму людини; 3) назва тривимірної фрігури в стереометрії [30].

Прояв у всьому цьому девальвації культурного статусу, сенсу людського тіла, його фрізичного іміджу виявляє себе і у відсутності або ж вкрай низькій актуалізації установки на культивування (від слова «культура», але не «культ») своїх тілесних, рухових якостей, що характерно для представників різних соціальних груп [3, 5]. Так, за даними численних досліджень, серед дорослого населення відсоток тих, хто більш-менш постійно приділяє цьому увагу, коливається в межax 6-15\% [4].
Тілесна репрезентація відіграє особливу роль в оцінюванні особистих якостей індивіда, його психологічних і когнітивних особливостей і служить відправною точкою у визнанні індивіда або виключення його/ї̈ з соціальної групи. Індивідам з красивими спортивними тілами приписуються такі якості, як сила волі, цілеспрямованість і чуття стилю [23]. Відповідно, створюючи нове тіло, індивід створює майбутне 3 новими перспективами. Якщо ж він не здатний створити правильний (відповідний очікуванням 3 боку суспільства і/або соціальної групи) тілесний перформанс, то це може служити причиною виключення з групи, маргіналізації, засудження, негативної оцінки.

Сучасна культура диктує суворі канони тілесної норми, що поширюються через різноманітні механізми громадського регулювання. Жіночому тілу приділяється особлива увага в публічному дискурсі, у зв'язку з чим стурбованість тілом, його розмірами і фрормою, стає нормативною. Жіноче тіло піддається особливій регламентації - воно контролюється, нормується, підганяється під параметри, вимірюється інструментально [23].

Сучасна тілесна культура, заснована на споживчому капіталізмі, пропонує цілий спектр нормуючих маніпуляцій з видалення волосся, позбавлення від запахів, догляду за шкірою та надання формам тіла потрібних обрисів. 3 позиції соціальної політики, жіноче тіло розуміється як демографічний ресурс, чию фертильність необхідно берегти і раціонально використовувати для вирішення важливих державних завдань, тоді як сучасна масова культура об'єктивує і розглядає його як зосередження сексуальності. В результаті відмінностей між імперативами, виробленими в політичному і ринковому дискурсі, жіноче тіло виявляється схильним до взаємовиключних, амбівалентних вимог здоров'я, при- вабливості, фрертильності, молодості, стрункості. На відміну від чоловіків, жінки не просто володіють тілами, а й асоціюються 3 ними [23].

Новим культурним імперативом стає не тільки худе, а й підтягнуте і спортивне тіло. Поряд зі здоровим харчуванням воно вважається маркером успішності, а більша частина жіночого тілесного досвіду виявляється витісненою у сореру ненормального. Як показують дослідження, в сучасних розвинених країнах жінки частіше, ніж чоловіки, висловлюють невдоволення власним тілом [23].

Тілесна культура, яка домінує в різних дискурсивних просторах - державній політиці, медицині, мас-медіа, сім'ї та групах однолітків, припускає незадоволеність тілом як відправної точки для подальшої роботи над собою [23].

Відповідна віку тілесна соціалізація відіграє важливу роль в отриманні визнання, особливо в молодіжних субкультурах. Для молодих людей моніторинг і оцінювання як свого власного тіла, так і однолітків стає рутинним заняттям. Вони вчаться оцінювати себе та інших, орієнтуючись на «правильні» тілесні образи, які диктує ринок, що може призводити до утвердження «ієрархій прийнятності» (hierarchies of acceptability) як особистих, так і групових [23].

Деякі дослідники пропонують розглядати людину як систему 3 пірамідальною композицією принципу побудови (так звана піраміда Абрахама Маслоу), в якій виділено три рівні: нижчий - тілесний, середній - психічний і вершина - духовний.

Ставлення до тіла людини - питання, що збуджує думки фрілософрів, культурологів, психологів, істориків, антропологів, педагогів протягом тисячоліть [1, 5]. Можна сказати, що просторова організація тіла людини як особливий об'єкт наукового і громадського інтересу пройшла довгий, тернистий шлях. Спроби дослідження закономірностей розподілу в просторі маси тіла людини мають багатовікову історію. Прагнення до вивчення та виявлення закономірностей у розмірах людського тіла виникло у Стародавньому Єгипті. Провідним моти- 
вом культури античності є ідея гармонії тілесного і духовного в людині, та їх взаємозв'язку [10].

Вивчення тіла людини посилилося в епоху розквіту грецького класичного мистецтва. Еталонами краси людського тіла, зразками гармонії статури здавна вважаються великі твори грецьких скульпторів Фідія, Поліклета, Мирона, Праксителя. Краса тіла людини, її форми і пропорції особливо цінувалися греками. Тип краси - це культ краси людського тіла. В епоху Стародавньої Греції культ тіла визначався і більш прагматичними причинами. Гармонійний фрізичний розвиток, спритність, сила були необхідні для захисника вітчизни, тобто для військових цілей. Давньогрецькій культурі був притаманний пошук «пропорції зв'язку речей», математичних законів краси і гармонії, пошук ідеалу людського тіла і духу [10].

Найвищих результатів у вивченні закономірностей просторової організації тіла людини було досягнуто в епоху Відродження. Уже в той час вчені відзначали, що система співвідношень частин людського тіла для максимальної стійкості всього організму повинна слідувати співвідношенню гармонії - «золотого перетину», яке займає провідне місце в художніх канонах Леонардо да Вінчі. Сам митець у праці «Про божественну пропорцію» наводить малюнок: фрігура людини - «Вітрувіанська людина» - вписана в коло і квадрат, де всі частини тіла симетричні. За модуль Леонардо да Вінчі брав висоту голови, яка вісім разів укладається в довжині тіла. Малюнок сам по собі часто використовується як символ внутрішньої симетрії людського тіла.

Взаємовідносини людини і 30 внішнього середовища 3 давніх часів цікавили дослідників. Так, в XVII ст. Р. Декарт вивчав «механіку зовнішнього тіла», розглядаючи живий організм як своєрідну машину. Але для роботи машини, їі запуску необхідний ключ, який заводить і пускає в хід механізм машини. Так виникла думка про значення зовнішніх стимулів у виникненні поведінки людини.

Розгляд просторової організації тіла людини через призму біомеханіки став предметом досліджень ряду видатних науковців. Значним внеском у сучасне розуміння просторової організації тіла людини, формування його теоретичних основ був результат багаторічної праці професора А. М. Лапутіна та його учнів. Ще, у 1969 р. він розробив першу біомеханічну класифрікацію опорно-рухового апарату, принципи біомеханічного моделювання його суглобів та окремих ланок, сфрормулював принципи аналізу так званих локомоторних механізмів [24] Це дало змогу на більш об'єктивній основі будувати біокінематичні схеми опорно-рухового апарату під час аналізу рухів людини. Глибокий мислитель і експериментатор, людина 3 колосальним дивовижним світоглядом, практичним досвідом, великодушний гуманіст по суті професор А. М. Лапутін заклав основи вітчизняної біомеханіки, кінезіології та кінетики, які є втіленням системного підходу до вивчення рухової функції людини в онтогенезі. Учений володів талантом бачити перспективи розвитку науки, прогнозувати її головні напрями, одним із яких стало формування просторової організації тіла людини в онтогенезі.

Формування просторової організації тіла відбувається під впливом як біологічної, так і соціальної програми розвитку. Понад сто років тому людину сприймали насамперед за поставою. Мало значення все: як вона стоїть, сидить, наскільки високо тримає голову. Від постави залежало, чи будуть її поважати і захоплюватися нею в суспільстві. «Гарний той, хто з'являється красиво»,- свідчив старовинний афоризм.

Постава відображає уявлення людини про власне тіло і відіграє помітну роль у формуванні власного іміджу в очах оточуючих. У поставі можна побачити відображення ставлення людини до соціальних і індивідуальних цінностей, до краси і загальнолюдських ідеалів. Прагнення набути правильної постави є значущим фактором фрормування естетичної культури, оскільки характеризує емоційне та інтелектуальне життя особистості, виходячи з її внутрішніх спонукань до пізнання прекрасного.
Якщо між просторовою організацією біоланок тіла і функцією організму існує певний взаємозв'язок, то правильна, раціональна, постава визначає гармонійний фрізичний розвиток і нормальний психічний стан людини. Функціональні порушення опорно-рухового апарату (ОРА) людини (сколіотична постава, кругла, плоска, кругло-увігнута і плоско-увігнута спина) створюють в організмі умови для розвитку цілого ряду захворювань хребтового стовпа. За зовнішнім виглядом постава характеризується формою хребтового стовпа і грудної клітки, розташуванням голови, плечового пояса, тулуба і таза, верхніх і нижніх кінцівок.

Результати численних досліджень [10, 12, 15, 32, 34] свідчать, що під час порівняння гоніометричних показників нормальної постави 3 показниками різних видів їі порушень спостерігаються статистично достовірні зміни. Порушення постави призводять до недостатньої рухливості грудної клітки і діафрагми, до зниження ресорної функції хребта, зменшення коливання внутрішньогрудного і внутрішньочеревного тиску. Ці зміни несприятливо позначаються на діяльності серцевосудинної і дихальної систем, на роботі органів травлення: знижуються їхні фрізіологічні резерви, порушуються адаптаційні можливості організму, працездатності, з'являється головний біль [34, 35, 38, 39].

Функціональні порушення ОРА визначають особливості особистісного реагування дитини на фрізичну ваду як пасивно-оборонний чи агресивнозахисний метод. Л. С. Виготський [6] переконував, що будь-яка тілесна вада є чинником, що змінює стосунки людини 3 навколишнім світом і в результаті дає «соціальну ненормальність поведінки».

Відомий англійський дослідник Чарльз Дарвін у книзі «Про вираження емоцій у людей і тварин» [8] ввів поняття «рефлекс постави»: «певні рухи і пози (іноді значною мірою) здатні викликати відповідні емоції... Набудьте сумної пози і через деякий час ви будете сумувати... Емоції спонукають до руху, але і рухи викликають емоції». 

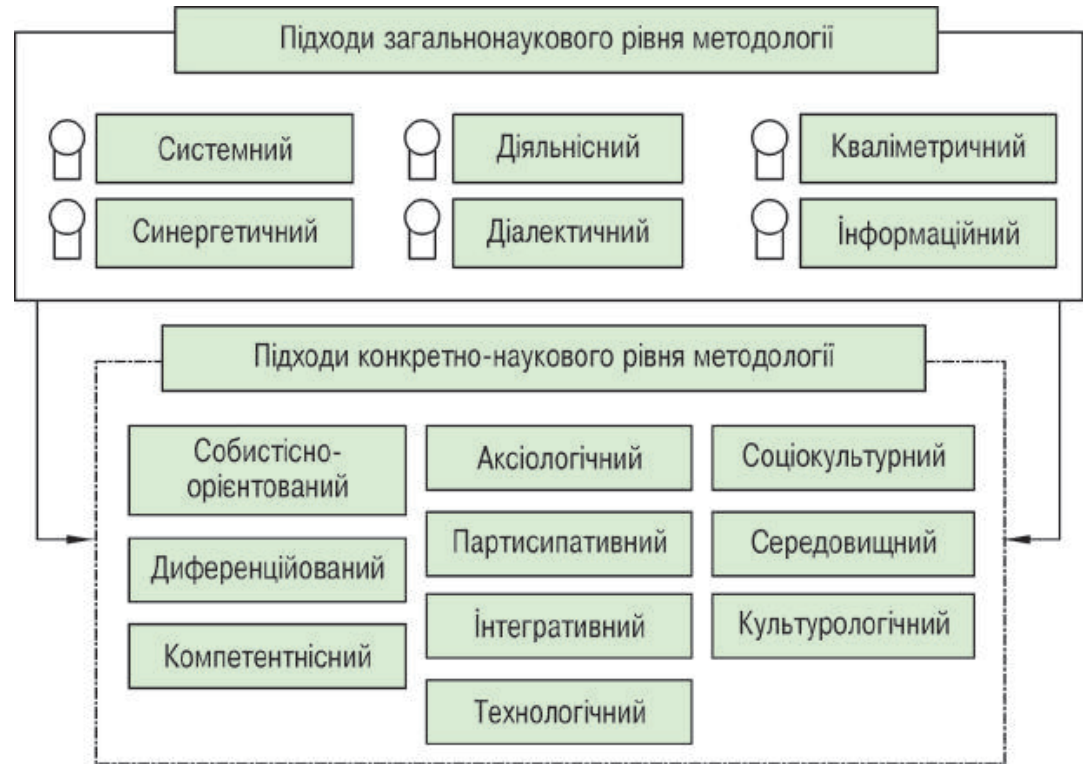

Рисунок 1 - Теоретико-методологічна основа концепції фрормування просторої організації тіла людини

Вплив психічного стану на поставу людини можна спостерігати в усіх випадках стресу, важких нервових потрясіннях, великому горі, які, зазвичай, негативно позначаються на зовнішньому вигляді людини, перш за все на поставі: похилена голова, опущені плечі, зігнута спина - часто роблять її невпізнаваною $[33,34,36]$.

Успіхи сучасної біомеханічної методології відкривають певні перспективи для подальшого удосконалення засобів і методів формування просторової організації тіла людини.

Мета дослідження - на основі теоретичного аналізу і власних експериментальних досліджень обгрунтувати та розробити концепцію формування просторової організації тіла людини у процесі занять фрізичними вправами, для підвищення ії̈ здоров'ясрормуючої та здоров'язберігаючої спрямованості.

Методи дослідження: теоретичні, соціологічні, антропометричні, біомеханічні, педагогічні, кваліметрії та математичної статистики.

Результати дослідження та їх обговорення. Виходячи 3 аналізу існуючих напрацювань науковців, визначено концептуальні підходи загальнонаукового та конкретно-наукового рівнів методології, що становлять теоретико-методологічну основу концепції (рис. 1).
Системний підхід являє собою напрям методології наукового пізнання й практичної діяльності, суть якого полягає в розгляді об'єктів як систем [31]. У нашому дослідженні організм людини - це система, яка має за мету свого існування цільову фуннцію та складається 3 менш складних підсистем (фрункція - процес, який відбувається в середині системи й дає певний результат) [2].

Синергетичний підхід - система заходів 3 формування просторової організації тіла людини, розглядається як складне цілісне системне явище, фуункціонування якого потрібно досліджувати на основі комплексного вирішення проблеми можливих порушень просторової організації з урахуванням усіх взаємозв'язків, впливу внутрішніх і зовнішніх факторів. Його розглядають у нерозривній єдності 3 системним підходом.

Діяльнісний підхід спрямований на організацію фізкультурно-оздоровчої діяльності, тому що тільки через системну спеціально організовану діяльність та отриманий досвід людина може усвідомити формування просторової організації тіла як мету саморозвитку, пізнає способи покращення просторової організації тіла, фрормує особистісні якості, ціннісне ставлення до власного здоров'я.
Діалектичний підхід ґрунтується на засадах діалектики, що тлумачиться як наука про найзагальніші закони розвитку природи, суспільства й мислення. В основу діалектичного підходу покладено фрілософський метод дослідження природи та суспільства, за допомогою якого можна зрозуміти складний, сповнений суперечностей шлях становлення об'єктивної істини, зв'язок на кожному ступені розвитку науки елементів абсолютного та відносного, усталеного й змінного, переходи від одних форм узагальнення до інших [2, 31]

Кваліметричний підхід передбачає методологічний напрям дослідження просторової організації тіла людини на основі використання положень кваліметрії, базується на концептуальних положеннях теорії та методики фрізичного виховання, теорії вимірів, моделювання та математичної статистики.

Інформаційний підхід спрямований на розгляд особливостей циркуляції інсрормації у педагогічних системах, орієнтований на оцінку ступеня інформаційної насиченості педагогічного процесу, дозволяє охарактеризувати механізми отримання, передачі, розпізнавання, перетворення та збереження інсормації, що має велике значення для досягнення запланованих результатів [31].

Особистісно-орієнтований підхід полягає у спрямуванні зусиль учасників фізкультурно-оздоровчої діяльності на оволодіння знаннями, уміннями та навичками 3 формування просторової організації тіла людини з урахуванням рівня індивідуального досвіду, потреби в самоорганізації та саморозвитку, формування особистості через розкриття його фізичного й психічного потенціалів.

Диференційований підхід характеризується створенням різноманітних умов, варіюванням засобів, методів фізичного виховання для врахування особливостей контингенту учасників фізкультурно-оздоровчої діяльності. Умовою реалізації диференційованого підходу була побудова системи моніторингу під час фізкультурнооздоровчої діяльності та визначення критеріїв диференціації, серед яких 
можуть виступати показники просторової організації тіла людини, рівень фрізичного стану, психологічні особливості особистості.

Аксіологічний підхід - дотримання основних позицій аксіологічного підходу передбачало визначення провідної ціннісної орієнтації (здоров'я) й основних способів, умов його фрормування в процесі фрізкультурно-оздоровчої діяльності. Завданням $є$ ссрормувати у особистості ціннісне ставлення до власного здоров'я, стимулювати її зацікавленість та активність у процесі фрізкультурно-оздоровчої діяльності. Але особливістю реалізації цієї діяльності $€$ неможливість нав'язування особистості цінностей здоров'я й здорового способу життя, вони є індивідуальними, такими, які бачить сама особистість та інтерпретує їх відповідно до власних бажань і життєвих пріоритетів [7, 28].

Партисипативний підхід характеризує взаємодією учасників фізкультурно-оздоровчої діяльності в напрямі самоуправління нею, що передбачає активну участь кожного $з$ учасників у визначенні способів, форм діяльності на умовах співробітництва, неформального делегування повноважень із метою саморозвитку особистості [7]. Партисипація, за визначенням Е. В. Яковлева, Н. О. Яковлевої [31], - це принцип управління, що передбачає орієнтацію спільної діяльності на співробітництво, забезпечен- ня колективної відповідальності, співуправління.

Соціокультурний підхід застосовується у формуванні розуміння у людини канонів тілесної норми, культури здоров'я. В процесі реалізації соціокультурного підходу система заходів враховувала існуючу культурну спадщину, норми і цінності, домінування культурно значущої взаємодії між людьми під час заняття фрізичними вправами [29, 31].

Середовищний підхід передбачає створення у закладах освіти здоров'язберігаючого освітнього середовища, в результаті взаємодії з яким у людини формується спосіб життя, визначений умовами цього середовища [7].

Компетентнісний підхід у змісті здоров'ясрормуючих та здоров'якорегуючих технологій передбачає реалізацію набутих людиною знань з формування просторової організації тіла, цінностей здоров'я, дотримання засад здорового способу життя у конкретних життєвих ситуаціях.

Інтегративний підхід розглядається з позиції запровадження педагогічної інтеграції через створення міжпредметних, внутрішньопредметних, міжособистісних зв'язків [31].

Технологічний підхід характерний тим, що його суть полягає в забезпеченні такої організації фрізкультурнооздоровчої діяльності, яка, по-перше, орієнтована на досягнення діагнос- тично поставленої мети, спроектованої 3 урахуванням індивідуальних особливостей суб'єктів та організаційно-методичних умов здійснення діяльності, i, по-друге, оптимально алгоритмізованої до методів, засобів і форм, а також інформаційних, часових і міжособистісних характеристик.

Культурологічний підхід охоплює напрями діяльності 3 формування орієнтування особистості у культурних цінностях, осмислення та присвоєння особистістю культурних цінностей, створення нею своєї індивідуальності та цінності тощо. [31].

Понятійний апарат методології було ссрормовано у процесі узагальнення результатів проведених емпіричних спостережень і багаторічних педагогічних експериментів фрундатора біомеханіки спорту та фрізичного виховання професора А. М. Лапутіна та розширено у подальших наукових працях його учнів [14, 18-21].

Відповідно до системотвірної концептуальної ідей та запобігання смислового і змістового спотворення термінологічного апарату, проведемо деталізацію ключових понять концепції формування просторової організації тіла людини.

У процесі дослідження формування термінологічного апарату за мету було поставлено уникнення термінологічної варіативності, використання поряд з основним терміном його синонімів, що приводить до існування
Просторова організація тіла людини

Біогеометричний профіль постави

\section{Статодинамічна постава}

\section{Біомеханічні властивості стопи}

- єдність морфологічної та функціональної організації людини, що відображається в ії зовнішній формі.

- один з основних показників фізичного розвитку людини, який характеризує високодиференційовану загальну структуру розташування біокінематичних пар опорно-рухового апарату (ОРА) людини відносно соматичної системи координат. Характеризується лінійними, гоніометричними показниками тіла, топографією сили м'язів, біостатичними показниками стійкості тіла, геометрією мас тіла.

- характеризується вертикальним положенням тіла, що знаходиться у рівновазі і зміною в динаміці пози, і положення тіла з плином часу. При цьому вертикальне положення тіла людини з системних позицій оцінюється як певна гармонія взаємопов'язаних просторових характеристик їі тіла.

- характеризуються кутовими показниками: кут $\alpha$ - плюсневий кут (кут між лінією опорної частини склепіння стопи (/) і прямою, яка з'єднує головку першої плеснової кістки 3 точкою максимальної висоти склепіння) відображає ресорні властивості стопи, пов'язані з утриманням склепіння активними компонентами-м'язами; кут $\beta$ - п'ятковий кут (кут між лінією (/) та прямою, яка з'єднує опорну точку горба п'яткової кістки з максимальною висотою склепіння), відображає опорні властивості стопи, пов'язаний із пасивними компонентами ОРА, що обумовлюють особливості з'єднання кісток і зв'язкового апарату стопи; кут $\gamma$ характеризує опорно-ресорні властивості стопи в цілому $(180-(\alpha+\beta))$. 
Статура

Корекція гравітаційних
взаємодій тіла людини

Технологія

Здоров'яформуючі технології в освіті

\section{Здоров'язберігаючі технологіі}

\section{Здоров'якорегуючі технологіі}

Модуль

Методика

Принцип

Превентивна фізична реабілітація людини з функціональними порушеннями ОРА

\section{Профілактика порушень просторової організації тіла людини}

- одна з характеристик фізичного розвитку, яка дає об'єктивне уявлення про просторову організацію морсрологічних складових організму людини, пропорції, конституційні особливості тіла. Необхідно відзначити, що статура має виражені статеві, вікові та індивідуальні особливості та з системних позицій може розглядатися як взаємозалежна та взаємозумовлена сукупність морфоорункціональних компонентів тіла людини.

- це спосіб приведення маси їі тіла та мас окремих відносно рухомих його ланок до такого співвідношення, котре забезпечувало б задану їх взаємодію для ефективного вирішення конкретних рухових завдань.

- алгоритм біологічних, медичних, технічних, педагогічних та інших способів і засобів зміни стану рухової фрункції і властивостей організму людини в процесі занять фрізичними вправами, заснована на знаннях про методи і прийоми здійснення корекційнопрофрілактичних, кінезитерапевтичних, освітньо-виховних та рекреаційних заходів.

- спільна діяльність суб'єктів освітнього процесу з формування, збереження, відновлення, зміцнення здоров'я дитини на основі розвитку у неї свідомого ставлення до власного здоров'я, формування здатностей до конструктивного вирішення питань дотримання засад здорового способу життя.

- це процес організації педагогічного процесу на основі виборчого і строго спрямованого підходу до відбору та використання спеціальних засобів і методів, що дозволяє не тільки зберігати, а й накопичувати результуючий ефрект педагогічних впливів, а також враховувати перспективні завдання оздоровчого процесу.

- організація педагогічного процесу, що базується на виборі і реалізації таких інтенсивностей, обсягів і спрямованості педагогічних впливів, які є адекватними поточному стану організму тих, хто займається, і спрямовані на виправлення наявних відхилень у стані здоров'я людини.

- відносно самостійний елемент будь-якої технології, системи, необхідний для приведення в гармонійну відповідність розмірів і суті цілого і його частин.

- охоплює конкретні прийоми і способи, алгоритми або правила виконання певних послідовних спеціальноспрямованих дій, що дозволяють вирішити дослідницьке завдання.

- вихідне положення (правило), що визначає і регламентує діяльність педагога й учня відповідно до цілей фізичного виховання, закономірностей розвитку організму людини та умов його взаємодії з навколишнім середовищем.

- система педагогічних, біологічних, медичних, технічних та інших способів і засобів, грунтується на знаннях про методи і прийоми здійснення корекційно-просілактичних, кінезитерапевтичних, освітньо-виховних заходів, побудові ефективних прогностичних моделей біомеханіки ОРА людини, які $є$ адекватними поточному стану моторики, спрямованої на зміну просторової організації тіла людини, пружньов'язких властивостей скелетних м'язів, біодинаміки суглобово-зв'язкового апарату, геометрію мас тіла, що реєструються з використанням комп'ютеризованих діагностичних комплексів, візуальних скринінг-карт, технічних засобів, а також поетапного біомеханічного моніторингу з інфоормацією про результати реабілітаційних заходів.

- технологія педагогічного процесу, яка грунтується на побудові ефрективних прогностичних біомеханічних моделей просторової організації тіла людини відносно соматичної системи координат, спрямована на вдосконалення ії рухової функції. термінів із однаковим змістом та різних за означенням.

3 огляду на той фракт, що інтенсивне формування просторової організації тіла людини припадає на період шкільного онтогенезу, зокрема на молодший шкільний вік, у рамках вирішення основних завдань функціонування авторської методології термінологічний апарат дослідження було доповнено розробленими принципами здоров'яформуючої діяльності [7]:
- інноваційного проектування лідируюча позиція освітнього процесу 3 впровадження освітніх інновації. Запровадження принципу передбачає прогностичне проектування здоров'яформуючої діяльності у процесі фрізичного виховання дітей молодшого шкільного віку, яке ґрунтується на урахуванні нормативно-правових актів у напрямі здійснення освітнього процесу та збереження здоров'я дітей; впровадженні інноваційних за- собів фрізичного виховання, зарубіжного, вітчизняного передового досвіду для підвищення мотивів та інтересів дітей до активізації рухової активності;

- здоров'яформуючої валідності побудова комплексної системи моніторингу на основі педагогічних, психологічних, медико-срізіологічних, соціологічних досліджень, що визначають доцільність використаних певних засобів фрізичного виховання в рамках 
фрункціонування здоров'яфрормуючої технології для досягнення визначеної мети та перевірки відповідності результатів освітньої діяльності задекларованим;

- домінанта здоров'я дитини - побудова здоров'яформуючої діяльності у напрямі формування у дітей розуміння здоров'я як цінності, стимулювання психологічних механізмів розвитку у дітей відповідального ставлення до власного здоров'я, формування у суспільстві ціннісного ставлення до здоров'я в рамках функціонування взаємодії у системі сім'я-школа;

- триєдиного розуміння здоров'я дитини - потрібно уникати однобічного тлумачення стану здоров'я дитини, наприклад, тільки 3 позиції фізичного здоров'я, необхідно розглядати фізичну, психічну та соціальну складову у єдності;

- компетентності вчителя - готовність учителя для впроваджен- ня в процес фізичного виховання здоров'яформуючих технологій;

- системності - побудова планомірної здоров'ясормуючої діяльності, яка передбачає розробку спрямованого, контрольованого та регульованого алгоритму взаємодії всіх суб'єктів освітнього процесу (вчителя, учня, батьків) у напрямі формування здоров'я дітей, визначення окремих етапів та ефективне їх поєднання для раціоналізації даної діяльності та формування наступності педагогічного впливу.

Під час аналізу науково-методичної літератури [10, 15, 16, 22, 25] було систематизовано методологічний інструментарій оцінювання показників просторової організації тіла людини. ії багатогранність змусила розглядати дані підходи до оцінювання та згрупувати їх за групами: методики оцінювання стану ОРА, статури та складу тіла.
Методичні підходи до моніторингу просторової організації тіла людини останнім часом все більше стають орієнтовані на застосування інноваційних методів, що базуються на використанні сучасних інформаційних технологій [9]. У цьому напрямі колективом кафедри кінезіології та в подальшому - біомеханіки та спортивної метрології НУФВСУ розроблено програмні продукти, що відповідають сучасним вимогам моніторингових досліджень показників просторової організації тіла людини, а також зорієнтовані на створення теоретичного базису уявлень про просторову організацію тіла, як одного з показників здоров'я людини (рис. 2).

За своїм змістом ці програми слід класифрікувати на діагностичні програми та інфрормаційно-методичні системи. Суть діагностичних програм («Torso», «Bigfoot», «Footprint», «Biovidio») полягає у збиранні, ана-

\section{Антропометрія}

\section{Методи візуального скринінгу}

\section{Гоніометрія}

\section{Методи оцінювання функціонального стану ОРА}

\section{Відіометрія}

\section{Методики оцінки стану ОРА}

- сукупність методологічних прийомів у антропологічному дослідженні для вимірювання (соматометрія) та/або опису (антропоскопія) тіла людини в цілому або окремих її частин, а також для характеристики їх мінливості.

біогеометричного профілю постави - зіставлення показників біогеометричного профрілю постави людини зі спеціально розробленими картами. Критеріями для оцінювання слугують: положення голови та тулуба відносно вертикальної осі, стан вигинів хребтового стовпа, форма живота, кут у біопарі стегна та гомілки, положення плечей, нижніх кутів лопаток та кісток таза, трикутників талії та положення стоп. Інструментарій: карта оцінювання Posture Check, карта візуального скринінгу біогеометричного профілю постави дітей дошкільного віку (В. О. Кашуба, Н. Л. Носова, Т. В. Коломієць), школярів (В. О. Кашуба, Н. Л. Носова), студентів (В. О. Кашуба, Н. Л. Носова, М. В. Дудко); опорно-ресорних властивостей стопи - огляд медіального (внутрішнього) зводу стопи та підошвової поверхні обох стоп, визначення її фрорми, порівняння плантограм обстежуваних зі зразками типів стоп.

Інструментарій: методики Бохенека, Кларка та ін.

- метод реєстрації положення частин тіла людини, в тому числі під час руху. Використання даних підходів дозволяє дати кількісну характеристику вигинів хребетового стовпа, сплощеності стопи, обсяг згинання та розгинання стопи у надп'ятковогомілковому суглобі.

Інструментарій: гоніометр, сколіозометр, лордозоплечосколіозометр, сферосоматометр, сколіограф кіфосколіозометр, електрогоніометр, діагностичний комплекс «REV-9000», «МБН-БИОМЕХАНИКА» та ін.

- застосування рухових тестів дозволяє оцінити морфофрункціональні можливості м'язів тулуба (за результатами виміру амплітуди рухів у різних площинах та діапазонах рухів) та нижньої кінцівки людини, що забезпечують стато-локомоторну функцію. - визначення показників просторової організації тіла людини відповідно до соматичної системи відліку із застосуванням спеціального програмного забезпечення. Інструментарій: «Posture Pro Software System», «Yugami-ru», «RULA», «Posture Screen Mobile», «TORSO», «TeleMeter», «Big foot», «Foot print», «Ортопед». 


\section{Електоротензо-динамометрія, стабілометрія}

Антропометрія

Методи візуального скринінгу

Методи на основі визначення щільності тіла та його об'єму

\section{Біофізичні методи}

- визначення опорних взаємодій тіла людини під час природних статолокомоторних актів та виконання спеціальних рухових завдань.

Інструментарій: електронний апарат «Back-Check 607», тензодинамометричні устілки, платформа DIERS pedogait та ін.

\section{Методи оцінювання типу статури та складу тіла}

- передбачає визначення тотальних розмірів тіла, крім того аналізуються обхватні, скелетні розміри тіла та сегментів кінцівок, розмір шкірно-жирових складок. Застосовується розрахунок співвідношення антропометричних показників: метод індексів, методика визначення складу тіла за Я. Матейко, методики соматипування Р. М. Дорохова та В. Г. Петрухина, Хіт-Картера та ін.

Інструментарій: антропометр, ваги, циркуль товстотний та ковзний, циркуль-каліпер, сантиметрова стрічка.

- характеристика особливостей жировідкладень, розвитку мускулатури, форми грудної клітки, ніг, пропорційне співвідношення частин тіла людини. Розподіл за типами статури здійснюється відповідно до добору певних ознак.

Інструментарій: методика М. В. Черноруцького, Е. Кречмера, В. В. Бунака, В. Г. Штефко, А. Д. Островского.

- передбачають поміщення тіла людини у спеціально створені умови водного середовища чи розчину газу (гідростатична денситометрія, волюмінометрія, повітряна плетизмографрія).

Інструментарій: прилад для гідростатичного зважування (стаціонарний, портативний), волюмінометр, плетизмографр.

- грунтуються на аналізі фрізичних властивостей тканин тіла людини (методи розведення індикаторів, біоімпедансний аналіз, загальний метод електричної провідності, метод інфррачервоного відображення, визначення природної радіоактивності всього тіла).

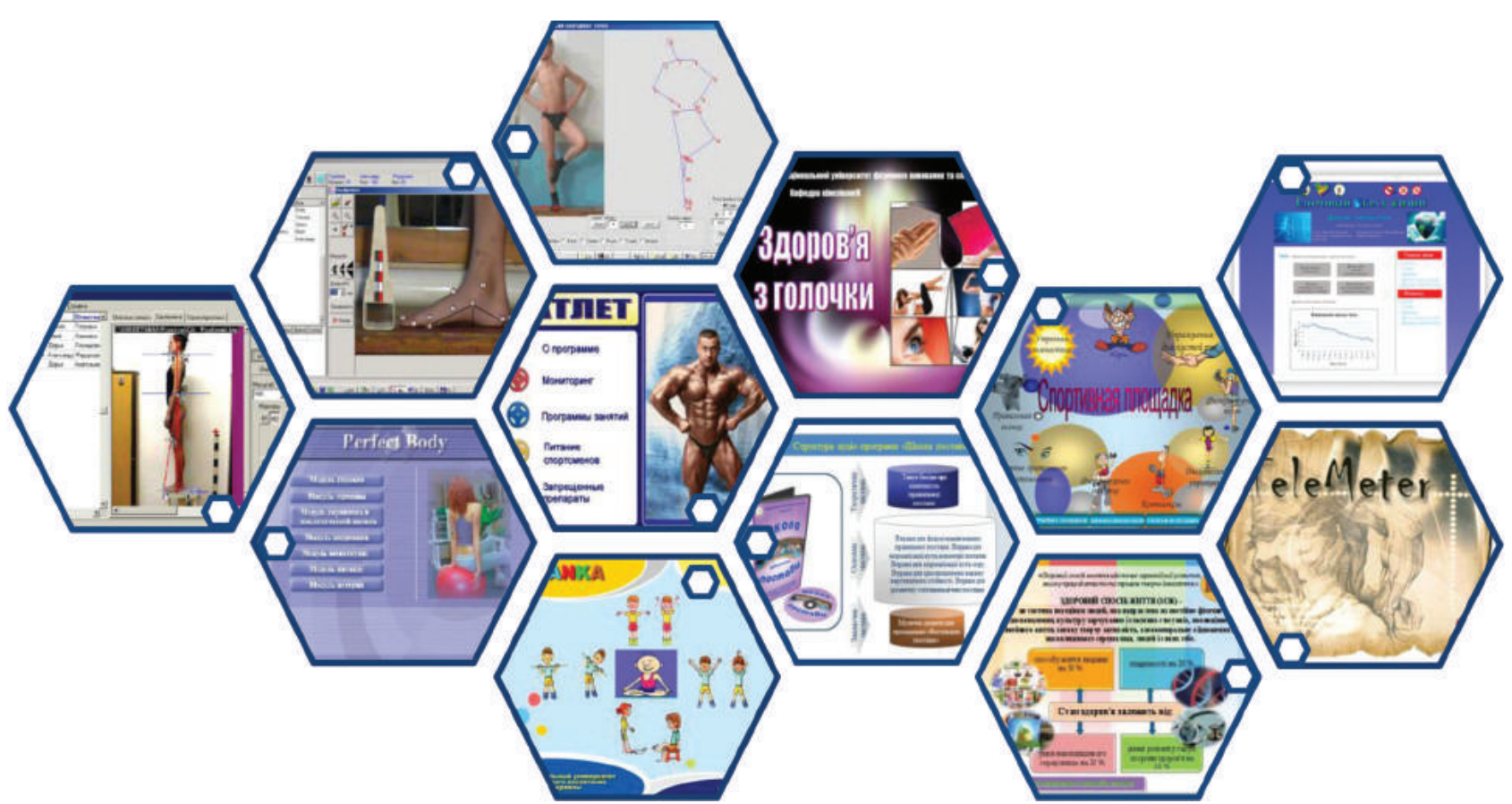

Рисунок 2 - Програмні продукти моніторингового та інсрормаційного супроводу формування просторової організації тіла людини в онтогенезі.

лізі та подальшому збереженні показників просторової організації тіла осіб різного віку через систему баз даних. Інформаційно-методичні сис- теми («Атлет», «Здоров'я з голочки», «Telemetr» та ін.) мають розширений зміст функцій, який передбачає окрім збирання та аналізу показників про- сторової організації тіла людини добір теоретичних відомостей рекомендаційного характеру до організації просрілактичних та корекційних захо- 


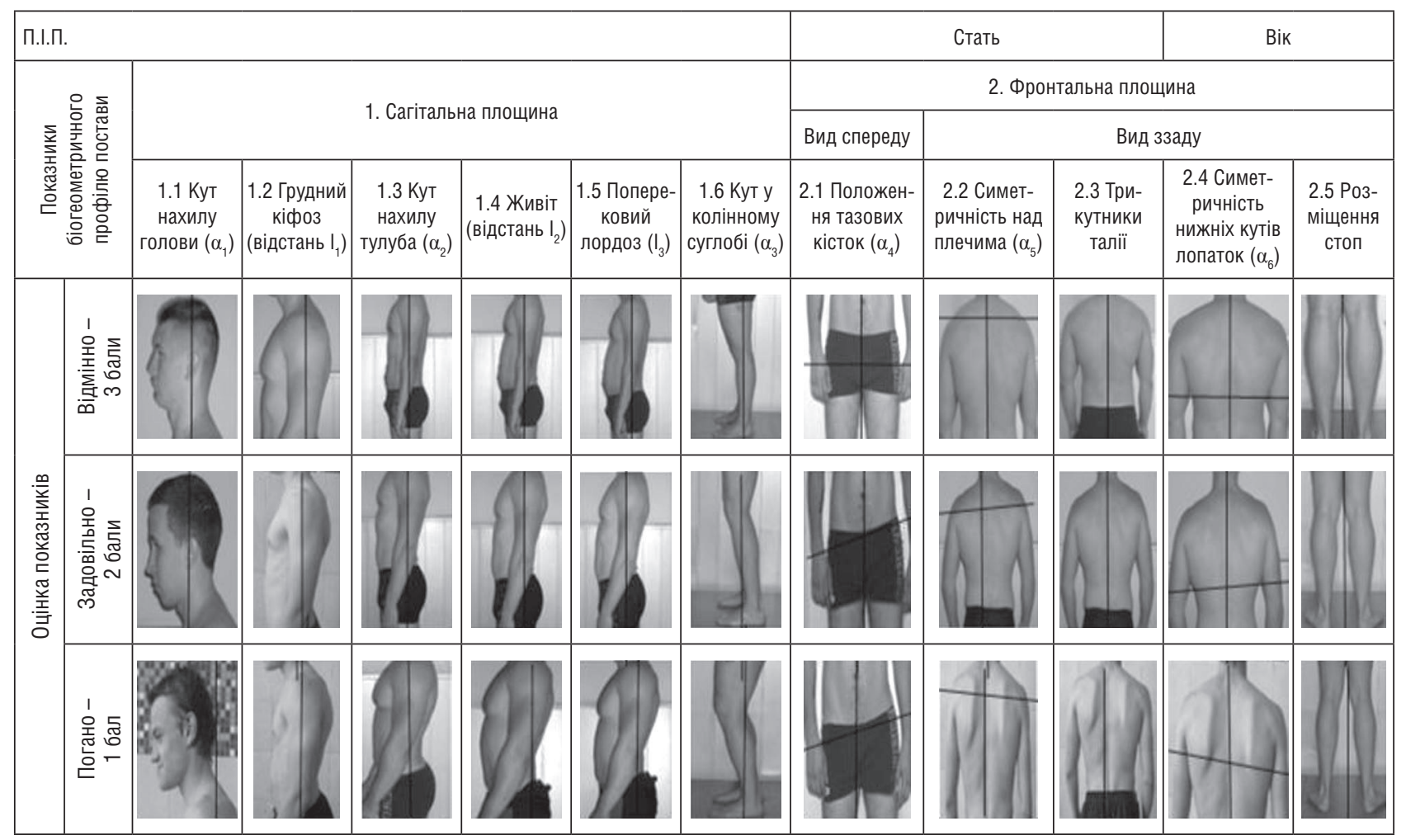

Рисунок 3 - Карта візуального скринінгу біогеометричного профрілю постави [11]

дів та формування загальнотеоретичних знань просторової організації тіла людини.

Досвід практичної діяльності проведення моніторингу просторової організації тіла людини спонукав до розробки методики скринінгу, яка $є$ незамінною під час масових обстежень та інфрормативною порівняно з інструментальними методами.

Для оцінювання стану біогеометричного профрілю постави запропоновано використовувати такі показники [15]: для сагітальної площини - положення голови і тулуба відносно вертикальної осі, стан грудного кіфозу і поперекового лордозу, форма живота, кут у біопарах стегна і гомілки; для фронтальної площини - розташування плечей, нижніх кутів лопаток і тазових кісток, трикутники талії, положення стоп.

Під час проведення візуального скринінгу біогеометричного профрілю постави максимальна кількість балів, яку міг отримати обстежуваний, за інтегральною оцінкою становить 33 бали, якщо всі 11 показників оцінено в 3 бали, мінімальна кількість дорівнює
11 балів, якщо всі 11 показників оцінено в 1 бал (рис. 3).

Відповідно до сумарної кількості набраних балів, автори розподілили обстежуваних за рівнями стану біогеометричного профілю постави: «низький» 11-16 балів; «середній» 17-23 бали; «високий» 24-33 бали.

Практичний досвід реалізації запропонованого підходу до масових досліджень стану біогеометричного профілю постави спонукав учених розглядати перспективи його застосування для різного контингенту досліджуваних - від дітей дошкільного віку до осіб зрілого віку - та автоматизації процесу обробки даних.

Так, наприклад, для дітей дошкільного віку шляхом розрахунку коесріцієнта конкордації Кендалла встановлено узгодженість думки експертів на рівні $W=0,92$ при $p<0,01$, щодо критеріїв оцінки біогеометричного профілю постави, які потребують врахування під час створення карти візуального контролю біогеометричного профілю постави дітей дошкільного віку (табл. 1).

За оцінками експертів, перелік найбільш важливих показників стану біогеометричного профрілю постави дітей 5-6 років становить: $у$ сагітальній площині - кут нахилу голови $(\bar{r} ; s)$ $(1,38 ; 0,52)$, величина грудного кіфозу $(\bar{r} ; s)(1,63 ; 0,52)$, кут нахилу тулуба $(\bar{r} ; s)(3,38 ; 0,52)$, величина поперекового лордозу $(\bar{r} ; s)(3,63 ; 0,52)$; у фронтальній площині - симетричність надпліч $(\bar{r} ; s)(1,63 ; 0,74)$, симетричність нижніх кутів лопаток $(\bar{r} ; s)(1,75 ; 0,71)$, постановка стоп $(\bar{r} ; s)(3,0 ; 1,07)$, симетричність тулуба $(\bar{r} ; s)(3,63 ; 0,52)$. Карта візуального експерт-контролю рівня стану біогеометричного профілю постави дітей 5-6 років охоплює по чотири показники в сагітальній і фронтальній площинах [17].

На основі інтегральної шкали здійснено оцінювання рівня стану біогеометричного профрілю постави, що містила верхню та нижню межі (кожен із показників припускав максимальну оцінку 5 балів, мінімальну - 1 бал, тобто максимально можливу оцінку біогеометричного профрілю постави становила 40 балів, а мінімальна - 8 балів).

Потреба в оперативній обробці та аналізі отриманих результатів спону- 
Т а б л и ц я 1. Показники біогеометричного профілю постави дітей 5-6 років, n = 8 [17]

\begin{tabular}{|c|c|c|c|}
\hline \multirow[b]{2}{*}{ Показники } & \multicolumn{3}{|c|}{ Розподіл за рангами } \\
\hline & $\begin{array}{l}\text { Середній } \\
\text { ранг, } r\end{array}$ & $\begin{array}{l}\text { Стандартне } \\
\text { відхилення, } s\end{array}$ & $\begin{array}{c}\text { Місце } \\
\text { у рейтингу }\end{array}$ \\
\hline \multicolumn{4}{|c|}{ Сагітальна площина $\mathrm{W}=0,92 ; \chi^{2}=44,04 ; \mathrm{p}<0,01$} \\
\hline Кут нахилу голови & 1,38 & 0,52 & 1 \\
\hline Форма грудної клітки & 1,63 & 0,52 & 2 \\
\hline Відставання лопаток & 5,44 & 0,76 & 5 \\
\hline Кут нахилу тулуба & 3,38 & 0,52 & 3 \\
\hline Форма живота & 6,50 & 0,76 & 7 \\
\hline Величина поперекового лордозу & 3,63 & 0,52 & 4 \\
\hline Кут у колінному суглобі & 6,06 & 0,64 & 6 \\
\hline \multicolumn{4}{|c|}{ Фронтальна площина $\mathbf{W}=0,93 ; \chi^{2}=37,36 ;$ p $<0,01$} \\
\hline $\begin{array}{l}\text { Вертикальне положення голови, вигляд } \\
\text { зі спини }\end{array}$ & 5,88 & 0,35 & 6 \\
\hline Симетричність надпліч & 1,63 & 0,74 & 1 \\
\hline Симетричність тулуба (трикутники талії) & 3,63 & 0,52 & 4 \\
\hline Симетричність тазових кісток & 5,13 & 0,35 & 5 \\
\hline Симетричність нижніх кутів лопаток & 1,75 & 0,71 & 2 \\
\hline Постановка стоп & 3,00 & 1,07 & 3 \\
\hline
\end{tabular}

кала до удосконалення карти візуального скринінгу стану постави на основі використання інорормаційних технологій у вигляді програми «Habitus» (рис. 4).

Зважаючи на вагомість для формування постави ортоградного положення тіла управління ортоградною позою дітей 5-6 років, програмою також передбачено визначення локалізації загального центру маси (ЗЦМ).

Побудову математичних моделей опису взаємозв'язку ЗЦМ дітей 5-6 років і показників просторової організації їхнього тіла уможливив регресійний аналіз на основі MS Excel, за результатами якого констатовано: при $p<0,05$ статистично значущими є такі складники моделі, як довжина плеча (ДП), довжина гомілки (ДГ), центр мас (ЦМ) гомілки та ЦМ стопи. заційну структуру моніторингу про- сторової організації тіла людини в процесі занять фрізичними вправами (рис. 5). Реалізація даної організаційної структури передбачає послідовні етапи із дотриманням певного алгоритму та умов проведення.

Результатом проведення моніторингу є не тільки сукупність даних показників просторової організації тіла людини, а ще добір певних управлінських рішень із профрілактики та корекції виявлених порушень. Практичну реалізацію заходів профрілактики та корекції порушень просторової організації тіла людини слід представити у вигляді сукупності здоров'яформуючих та здоров'якорегуючих технологій, які реалізуються в процесі ффізичного виховання та превентивної фрізичної реабілітації.

Конкретизуючи методичні напрацювання, що стосуються змісту здоров'ясрормуючої діяльності впливу на показники просторової організації тіла людини, розглянемо запропоновані технології для контингенту дітей молодшого шкільного віку.

У межах виконання наукової роботи запропоновано структуру та зміст здоров'ясрормуючих технологій у процесі фрізичного виховання (рис. 6), метою яких $є$ теоретичне обґрунтування, розробка та впровадження комплексу заходів здоров'ясормуючої діяльності, спрямованих на формування просторової організації тіла людини, покращення рівня фрізичного стану, рухової активності, мотивації до систематичних занять фрізичними вправами. Етапами реалізації здоров'яформуючих технологій були визначені адаптаційно-підготовчий, основний, заключний.

Структуру адаптаційно-підготовчого етапу визначає попередній моні-

Т а б л и ц я 2. Результати процесу вдосконалення регресійної моделі засобами MS Excel: складники моделі є статистично значущими при $\mathrm{p}<0,05$ )

\begin{tabular}{|l|c|c|c|c|c|c|}
\hline \multicolumn{1}{|c|}{ Показники } & $\mathbf{a}_{\mathbf{i}}$ & $\mathrm{s}$ & $\mathbf{t}$ & $\mathbf{p}$ & Нижні 95 \% & Верхні 95\% \\
\hline Ү-перетин & 0,510 & 0,083 & 6,147 & 0,000 & 0,343 & 0,677 \\
\hline ДП & 0,012 & 0,002 & 5,295 & 0,000 & 0,007 & 0,016 \\
\hline ДГ & 0,003 & 0,001 & 2,768 & 0,008 & 0,001 & 0,005 \\
\hline ЦМ_Г & $-0,010$ & 0,003 & $-3,485$ & 0,001 & $-0,016$ & $-0,004$ \\
\hline ЦМ_С & $-0,016$ & 0,007 & $-2,375$ & 0,022 & $-0,030$ & $-0,002$ \\
\hline
\end{tabular}




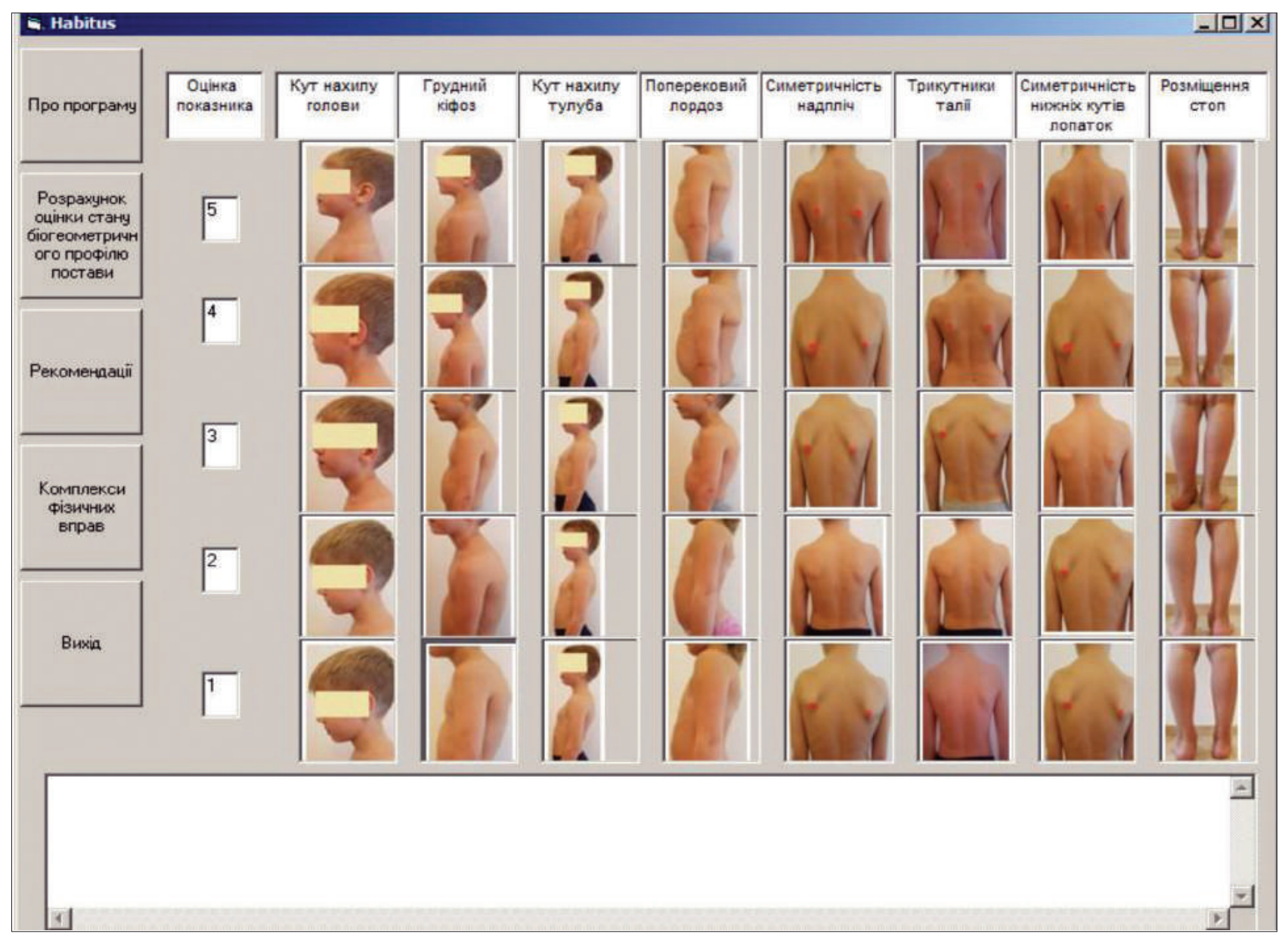

Рисунок 4 - Вікно інформаційно-аналітичної системи «Habitus»

торинг вихідного стану та з'ясування наявності можливих фракторів негативного впливу на стан просторової організації тіла та здоров'я дитини, окреслення провідних засобів, фрорм та методів реалізації технологій та безпосередня розробка програм занять на основі використання різних видів рухової активності.

Основними завданнями, які вирішуються на даному етапі, є: здійснення попереднього моніторингу показників просторової організації тіла, фрізичного стану дітей молодшого шкільного віку, особливостей перебігу адаптаційних процесів до умов навчання в школі, наявності факторів ризику для здоров'я дитини, рівня набутих теоретичних знань та практичних умінь здійснення здоров'яформуючої діяльності; формування та вибір засобів, форм і методів здоров'яформуючої діяльності, які покладено в основу проекту технологій; безпосереднє створення практичної фрорми реалізації технологій у вигляді програм занять.
Наступним етапом реалізації здоров'яформуючих технологій є основний, у межах якого відбувається досягнення мети та вирішення основних завдань. Побудова програм занять визначається досягненням оздоровчого ефректу із урахуванням сенситивних періодів розвитку рухових якостей дітей молодшого шкільного віку. Превентивна складова програм впливу обумовлена профілактичною діяльністю відносно найпоширеніших форм патологій у дітей. Реалізуються поточна та етапна фрорми контролю.

Заключний етап технологій передбачає визначення рівня досягнення запланованих результатів за повним спектром показників за основними критеріями оцінки ефективності у фрормі підсумкового контролю. Значну роль при цьому відіграє аналітична складова моніторингових досліджень, яка дозволяє окрім отримання результатів ефективності технології провести детальний її аналіз для досягнення запланованих завдань та прийняти відповідні управлінські рішення 3 підвищення ефективності.

Серед ключових положень функціонування здоров'ясрормуючих технологій з позиції профілактики порушень просторової організації тіла слід наголосити на таких [7]:

- у процесі здоров'яформуючої діяльності слід надавати перевагу фрормі занять позаурочного типу в режимі дня без уроку фрізичної культури та вихідного дня, грунтуючись на притаманних контингенту дітей молодшого шкільного віку особливостях рухового режиму та обсягу оздоровчої рухової активності;

- заняття повинні відповідати віковим особливостям організму дитини, мати регулярний характер із прогресуванням тренувальних дій згідно 3 основними принципами побудови занять 3 фрізичногоу виховання; 


\begin{tabular}{|c|c|}
\hline $\begin{array}{l}\text { Стан } \\
\text { просторової організації } \\
\text { тіла людини }\end{array}$ & $\begin{array}{c}\text { Детермінанти впливу на формування просторової організації тіла людини: } \\
\text { захворювання та несвоєчасний контроль, ергономіка, статодинамічний режим, } \\
\text { руховий режим, екологія, спадковість, харчування }\end{array}$ \\
\hline $\begin{array}{c}\text { Іेнформаційно-методичні } \\
\text { засоби біомеханічного } \\
\text { моніторингу }\end{array}$ & $\begin{array}{c}\text { Функції моніторингу просторової організації тіла людини: } \\
\text { підзвітності; інформаційно-просвітницька; прийняття рішень; } \\
\text { наукового прогресу; адміністративного моніторингу }\end{array}$ \\
\hline $\begin{array}{l}\text { - протоколи оцінювання; } \\
\text { - анкети експертного оцінювання; } \\
\text { - методичні вказівки; } \\
\text { - комп'ютерні програми } \\
\text { оцінювання показників }\end{array}$ & $\begin{array}{l}\text { Умови проведення моніторингу просторової організації тіла людини: } \\
\text { - діагностико-прогностичної спрямованості моніторингу; } \\
\text { - надійність одержуваної інформації; } \\
\text { - систематичність моніторингових досліджень; }\end{array}$ \\
\hline $\begin{array}{c}\text { Етапи моніторингу } \\
\text { просторової організації } \\
\text { тіла людини } \\
\text { попередній } \\
\text { визначення вихідних показників }\end{array}$ & $\begin{array}{l}\text { - оперативність подання інформації; } \\
\text { - доступність і простота форм представлення інформації суб'єктам } \\
\text { процесу фізичного виховання; } \\
\text { - обов'язкова педагогічна інтерпретація і дієве використання інформації, } \\
\text { одержуваної в результаті проведення моніторингу; } \\
\text { - консолідація зусиль учасників процесу моніторингу }\end{array}$ \\
\hline & Алгоритм біомеханічного моніторингу: \\
\hline $\begin{array}{c}\text { оперативний } \\
\text { визначення впливу занять } \\
\text { фізичними вправами на стан } \\
\text { просторової організаціі тіла }\end{array}$ & $\begin{array}{l}\text { - визначення критеріїв та підбір діагностичних засобів; } \\
\text { - визначення стану просторової організації тіла людини (біогеометричного } \\
\text { профілю постави, біомеханічних властивостей стопи, морфологічного } \\
\text { статусу, локалізації ЗЦМ, вертикальної стійкості тіла людини тощо); }\end{array}$ \\
\hline $\begin{array}{c}\text { підсумковий } \\
\text { оцінювання спрямованості адаптаційних } \\
\text { змін у просторовій організації тіла } \\
\text { людини між попереднім } \\
\text { і підсумковим контролем }\end{array}$ & $\begin{array}{l}\text { - оцінка та інтерпретація отриманих результатів; } \\
\text { тіла людини, виявлення передпатологічних станів; } \\
\text { - розробка індивідуальних рекомендацій до профілактики або корекції } \\
\text { порушень просторової організації тіла людини }\end{array}$ \\
\hline Здоров'яформуючі & Здоров'якоргуючі \\
\hline
\end{tabular}

Рисунок 5- Блок-схема організаційної структуи моніторингу просторової організації тіла людини у процесі фізичного виховання

- дисреренціація фрізичного навантаження повинна відбуватись згідно з результатами попереднього моніторингу показників просторової організації тіла, фрізичного стану дітей та здійснюватися за рахунок зміни умов виконання фрізичних вправ, варіювання загальної кількості повторень та тривалості виконання ффізичних вправ, зміни темпу виконання вправ із урахуванням індивідуальних особливостей організму дитини;

- до складу системи моніторингу повинні входити складові самоконтролю учнів під час виконання фрізичних вправ, потребують особливої уваги під час планування фрізичного навантаження недостатній розвиток суб'єктивного відчуття стомлення та неможливість об'єктивного мовлен- нєвого відображення внутрішнього стану, що характерно для контингенту молодших школярів;

- за чисельністю складу учасників слід надавати перевагу груповим та масовим формам занять, що обумовлює формування у дитини взаємодії у складі колективу учнів, досвіду групової діяльності та відповідальності;

- за предметним змістом заняття повинні відповідати мотивам та інтересам учнів і мати оздоровчу та рекреаційну спрямованість;

- під час визначення змісту засобів фрізичного виховання враховувати особливості структури захворюваності дітей молодшого шкільного віку. Так, у зв'язку із наявністю у значної кількості учнів захворювань кістково-м'язової системи слід віддавати перевагу симе- тричним вправам, значну увагу приділяти формуванню навички правильної постави, зміцненню м'язів спини, черевного преса та склепіння стопи, уникати компресійного навантаження на ОРА, сильних поштовхів та струсів тіла, перенапруження суглобово-зв'язкового та м'язового апарату, особливу увагу приділяти проявам порушення співвідношення довжини та маси тіла;

- у структурі засобів педагогічного впливу відокремити діяльність 3 розвитку функціональних систем організму відповідно до механізмів їх становлення у контингенті дітей молодшого шкільного віку, широко використовувати дихальні вправи, обмежити вправи із напруженням, подолання великих опорів, значного навантаження в циклічних рухах; 


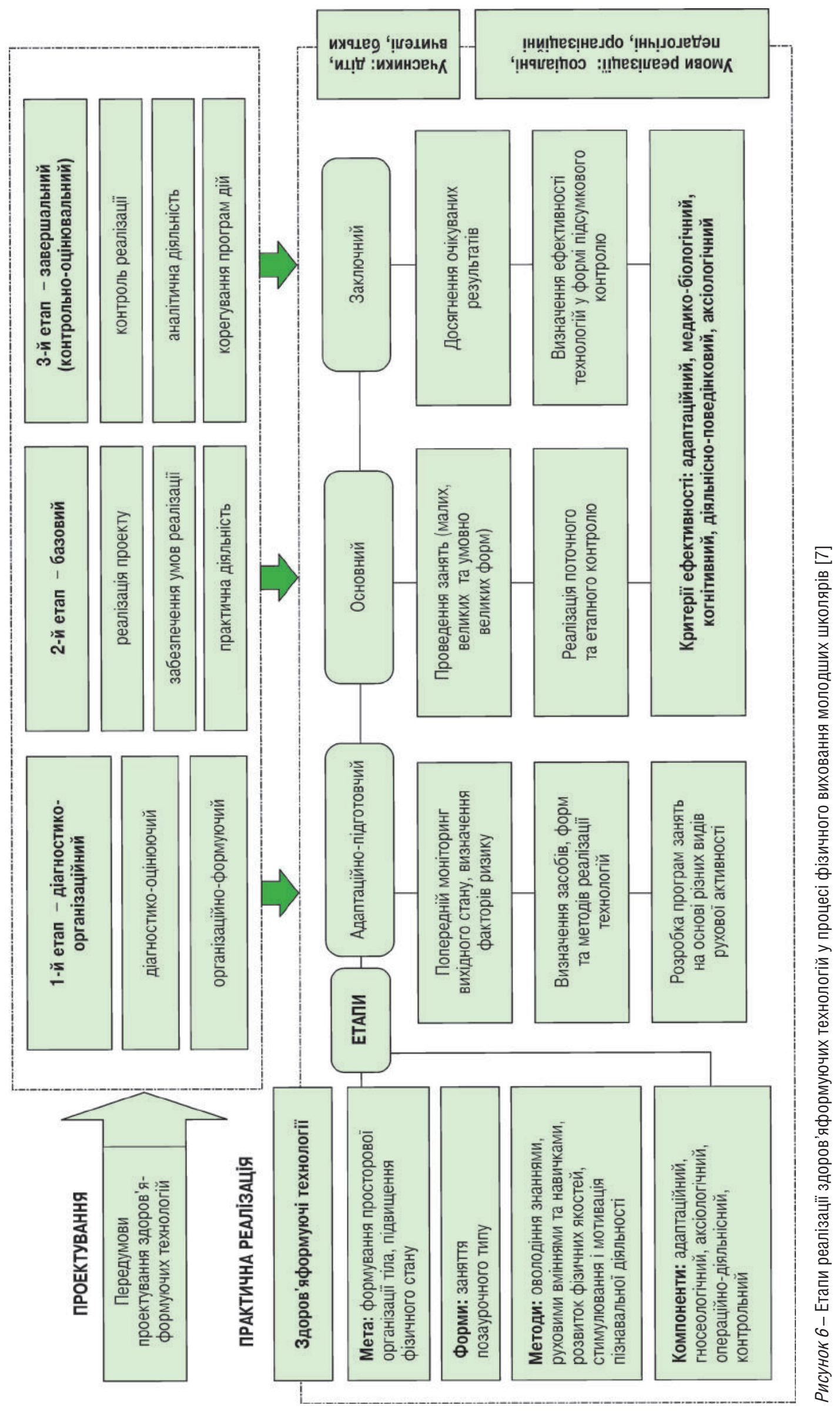


- значну увагу приділяти організації конкурсної діяльності, рухливим та сюжетним іграм, що супроводжуються високою емоційністю, можливістю уникнення монотонної діяльності, використовувати різноманітні рухові дії, дозволити реалізувати функції часткового управління та організації діяльності однолітків;

- під час планування заходів здоров'яформуючої діяльності учнів першого циклу навчання у початковій школі слід враховувати індивідуальні прогностичні показники адаптації до умов навчання в школі, наявність несприятливих фракторів впливу (медико-біологічних, психологічних та соціальних), темпи перебігу процесу адаптації до умов навчання;

- на орієнтаційному етапі адаптації до умов навчання в школі серед засобів педагогічного впливу віддавати перевагу фрізичним вправам ознайомчого характеру, що супроводжуються активним залученням батьків до здоров'ясоормуючої діяльності;

- дотримання принципів здоров'яформуючої діяльності.

У рамках технологій було розроблено програми занять, які за своїм змістом, у межах функціонування здоров'ясрормуючих технологій, складалися із таких компонентів: адаптаційний, гносеологічний, аксіологічний, операційно-діяльнісний. Вони відповідали вимогам програми 3 фізичної культури для учнів 1-4-х класів та основним напрямам діяльності 3 формування здоров'я дітей молодшого шкільного віку.

Адаптаційний компонент. Комплекс заходів і методів оптимізації процесів адаптації до умов навчання в школі, що визначаються індивідуальними особливостями перебігу процесів адаптації до умов навчання та фрізичного навантаження, нівелювання впливу несприятливих фракторів на здоров'я дитини, визначення індивідуального прогнозу адаптації дітей, налагодження співпраці з батьками в напрямі здоров'ясоормуючої діяльност та запобігання проявам дезадаптації в молодших школярів.

Операційно-діяльнісний компонент. Передбачає впровадження ком- плексів фрізичних вправ превентивної спрямованості (профрілактика порушень просторової організації тіла, захворювань органів та систем органів), комплекси загальної фрізичної підготовки на підвищення компонентів фрізичного стану, комплекси фрізичних вправ за обраним видом рухової активності, навички саморегуляції рухової діяльності. Зміст та форми реалізації операційно-діяльнісного компонента визначені видом рухової активності, що відповідає мотиваційним пріоритетам учнів.

Аксіологічний компонент. Передбачає комплекс заходів із фрормування культури здоров'я, мотивації до навчання та систематичної фрізкультурно-оздоровчої діяльності через системну діяльність із сприйняття здо ров'я людини як цінності, розуміння переваги дотримання засад здорового способу життя у повсякденній діяльності, що є основою майбутнього свідомого вибору в бік дотримання засад здорового способу життя.

Гносеологічний компонент. Включає складові теоретичної підготовки у напрямі дотримання засад здоро вого способу життя, також теоретичних відомостей про природу, правила поведінки у природних умовах, охорони природи, туризму як виду рухової активності та спортивної діяльності, знайомства з історичними, культурними, етнографічними об'єктами рідного краю.

Практична реалізація запропонованого підходу в процесі фрізичного виховання розглядалась на прикладі змістового наповнення програми занять засобами активного туризму, що реалізувалась в обсязі 216 годин на навчальний рік, за кратністю занять - тричі на тиждень. Відпо відно до основних компонентів зміст здоров'яформуючої діяльності визначався за такими складовими: загальна фрізична підготовка, туристська підготовка, підготовка орієнтувальника краєзнавство.

Основними формами реалізації заходів здоров'яформуючої діяльності були комплекси фрізичних вправ, сюжетно-рольові, рухливі ігри, естафети, туристські прогулянки, походи, масові фрізкультурно-оздоровчі заходи, фрізкультурні хвилинки, гімнастика.
Впровадження засобів туризму у зміст здоров'ясрормуючих технологій забезпечило їх наповнення різноманіттям видів діяльності, що особливо актуально для контингенту дітей молодшого шкільного віку. Засоби туризму в межах реалізації адаптаційного компоненту здоров'ясормуючої діяльності дали змогу реалізувати напрями діяльності із формування соціальної ролі учня як члена колективу, дотримання правил поведінки у ньому, налагодження взаємодій із однолітками та вчителем, набуття досвіду взаємодопомоги та взаємоповаги у колективі, розширити можливості саморегуляції рухової діяльності.

У процесі проведення дослідження сорормовано критерії, на основі яких визначено оцінку ефективності впровадження здоров'яформуючих технологій, серед яких адаптаційний, медико-біологічний, когнітивний, діяльнісно-поведінковий та аксіологічний.

Порушення просторової організації тіла належать до передпатологічних станів і можуть стати однією 3 серйозних причин виникнення фіксованих порушень ОРА у людини, тому нами було розроблено технологію превентивної фрізичної реабілітації дітей дошкільного віку з функціональними порушеннями ОДА.

Мета технології: обґрунтування та впровадження корекційно-профрілактичних заходів, спрямованих на корекцію та профрілактику функціональних порушень ОРА дітей старшого дошкільного віку засобами фрізичної реабілітації в умовах закладів дошкільної освіти (ЗДО).

Завдання технології: підвищення ефрективності процесу фрізичної реабілітації 3 корекції функціональних порушень ОРА дітей старшого дошкільного віку з урахуванням рівня стану їхнього біогеометричного профілю постави, моторики, біодинаміки суглобово-зв'язкового апарату; підвищення рівня стану біогеометричного профілю постави та фрізичних якостей дітей старшого дошкільного віку за рахунок використання у процесі превентивної фрізичної реабілітації ранкової гігієнічної гімнастики, занять ліку- 
вальною гімнастикою (ЛГ) із застосуванням фрітбол-гімнастики, аквафітнесу; створення стійкої мотивації до активних систематичних занять фрізичними вправами.

\section{Компоненти технологіі:}

- аксіологічний - актуальність компоненту полягає в необхідності реалізації в умовах ЗДО викликів часу, які виникають у зв'язку зі зміною соціокультурних запитів до максимально раннього фрормування культури здоров'я у дітей та ціннісного ставлення до нього. Посилюється у зв'язку із загостренням проблеми щорічного зниження рівня фізичного, психічного і соціального здоров'я дітей, що вступають до школи. Ця проблема була підтверджена багатьма дослідниками і відображена в Базовому компоненті дошкільної освіти України. Тому в процесі превентивної фрізичної реабілітації ставили за завдання сформувати у дитини ціннісне ставлення до власного здоров'я та його показників, особливу увагу приділяли поняттю «постава». Реалізація аксіологічного аспекту відбувалася під час бесід, тематичних занять, днів «Здоров'я». Аксіологічний компонент також дозволяє виявити рівень знань батьків та вихователів ЗДО про поняття «постава» та іï значення для здоров'я дитини;

- донозологічна діагностика - передбачає викопіювання даних медичних карток дітей дошкільного віку з метою виявлення типу їхньої постави; розробку карти візуального експресконтролю рівня стану біогеометричного профрілю постави дітей дошкільного віку; апробацію розробленої карти візуального експрес-контролю рівня стану біогеометричного профрілю постави дітей 5-6 років; оцінювання стану біогеометричного профілю постави дітей 5-6 років, визначення розташування ЗЦМ та біостатичних показників тіла, створення індивідуального й групового профрілів морфофункціонального статусу таких дітей, а також занесення інформації в бази даних у вигляді статистичних показників.

Технологія зорієнтована на реалізацію попереднього, оперативного й етапного контролю біогеометрич-

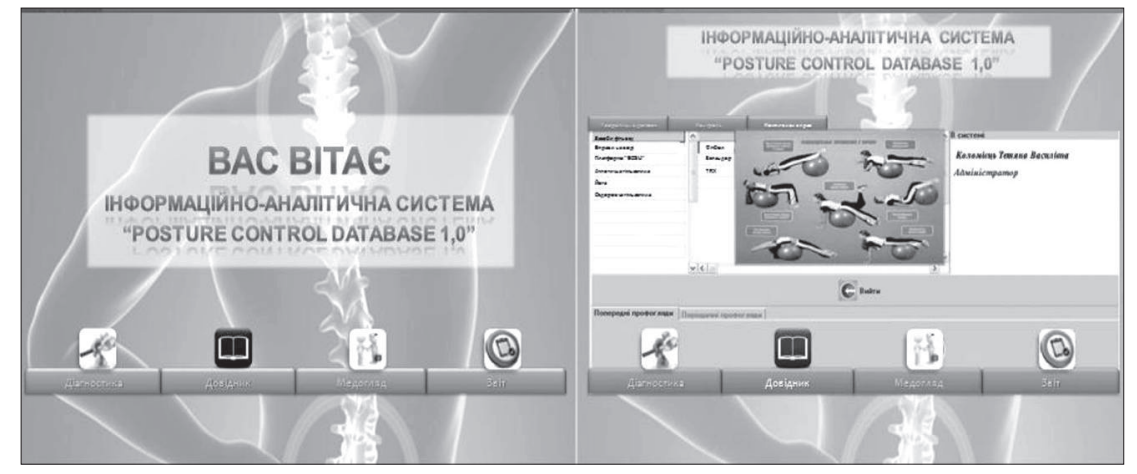

Рисунок 7- Вікна інсрормаційно-аналітичної системи «Posture control database 1,0»

ного профілю постави дітей старшого дошкільного віку протягом усього процесу фрізичної реабілітації. Попередній контроль біогеометричного профрілю постави дітей 5-6 років пов'язаний із визначенням рівня стану біогеометричного профрілю постави, біостатичних показників і розташування ЗЦМ тіла з використанням таких методів: візуальний скринінг, аналітичні методи (рекомендовано проводити на початку вересня); оперативний контроль - $з$ отриманням необхідної інфрормації про стан об'єкта з мінімальними часовими витратами та застосуванням візуального скринінгу за розробленою картою оцінювання рівня стану біогеометричного профілю постави (рекомендовано проводити протягом усього процесу фрізичної реабілітації); етапний контроль - з отриманням, обробкою й аналізом даних, які відображають завершений часовий етап або цикл і зумовлюють спрямованість подальших (рекомендовано проводити наприкінці травня з детальним вивченням та аналізом результатів попередніх вимірювань). Отримані результати уможливлюють оцінювання ступеня впливу корекційних заходів на рівень стану біогеометричного профрілю постави, внесення необхідних змін у процес фрізичної реабілітації з урахуванням індивідуальних особливостей рівня стану біогеометричного профрілю постави дітей. Загалом представлений алгоритм операцій забезпечує керованість контролю рівня стану біогеометричного профілю постави дітей 5-6 років у процесі фрізичної реабілітації;

- інсрормаційно-методичний - передбачає забезпечення фрахівців із фрі- зичної реабілітації необхідними методичними рекомендаціями до проведення вимірювання та оцінювання рівня стану біогеометричного профілю постави дітей 5-6 років; передбачає застосування програмного забезпечення, новітніх інформаційнокомунікаційних технологій, вебсайтів та Інтернет-сервісів 3 метою підвищення ефективності та доступності теоретичного матеріалу.

У контексті виявленої під час дослідження потреби у створенні бази даних рівня стану біогеометричного профілю постави, підвищення рівня теоретичних знань батьків і вихователів ЗД0 з просторової організації тіла дітей 5-6 років у дослідженні створено інформаційно-аналітичну систему «Posture control database 1,0», що є версією програмного забезпечення для здійснення контролю та корекційно-профрілактичних заходів стану біогеометричного профілю постави дітей дошкільного віку [27] (рис. 7).

Розроблена інформаційно-аналітична система «Posture control database 1,0» містить чотири вкладки («Довідник», «Скринінг», «База даних», «Звіт»), використання яких уможливлює:

- отримання теоретичних відомостей про поняття «постава», типи порушення постави; сучасні методи та засоби контролю, профілактики й корекції порушень постави та рівня стану біогеометричного профілю постави, а також комплекси вправ із відповідною демонстрацією;

- введення персональних даних обстежуваної особи; діагностування рівня стану біогеометричного про- 
філю постави дітей із граффічним результатом; отримання зведених і порівняльних даних попередніх оглядів у вигляді електронного чи друкованого звіту;

- викопіювання персональних даних дітей, обстежених лікарем-ортопедом, створення індивідуальної інформаційної бази даних, контроль дати наступного медогляду, відстеження динаміки показників стану постави;

- підбиття в цифровому, табличному та графічному вигляді підсумків діагностування або медогляду й окремо за кожною обстеженою особою та за конкретною групою певного обстежуваного контингенту осіб;

- корекційно-профілактичний передбачає впровадження корекційно-профрілактичних заходів, що мають за мету корекцію фрункціональних порушень ОРА дітей дошкільного віку відповідно до стану біогеометричного профілю постави; надання практичних рекомендацій до підвищення рівня стану біогеометричного профрілю постави дітей, зважаючи на те що корекція порушень просторових асиметрій біоланок тіла дітей охоплює такі напрями роботи, як спрямований вплив на порушення кутових і лінійних показників сагітального та фрронтального профілю постави дітей 5-6 років, нормалізація морфобіомеханічних порушень унаслідок фрормування оптимального рухового стереотипу, розвиток вертикальної стійкості тіла. В умовах впровадження засобів превентивної фрізичної реабілітації є доцільним використовувати такий алгоритм розробки корекційно-профілактичних заходів: оцінка рівня стану біогеометричного профрілю постави та біомеханіки стопи, розвиток вертикальної стійкості тіла; визначення цілей, завдань, критеріїв оцінювання та його ефективності в кожному конкретному випадку; визначення реабілітаційного прогнозу на основі наявних функціональних порушень ОРА, підбір оптимальних реабілітаційних заходів, термінів їх проведення, послідовності, безперервності, комплексного характеру програми, тривалості проведення реабілітації в цілому (наповнення програми реабілітації); реалізація корекційно-профрілактичних заходів із здійсненням контролю на кожному етапі її виконання; оцінювання реалізації корекційно-профрілактичних заходів, зіставлення отриманих результатів 3 поставленою метою; підготовка рекомендацій до подальшого ведення і спостереження дітей;

- критерійно-оцінювальний - забезпечував належну якість корекційно-профрілактичного процесу.

\section{Висновки:}

1. У процесі історичного розвитку виникали різні інтерпретації і трактування феномену людського тіла. 3 великого різноманіття розглянутих підходів можна виділити такі: побудова моделей людського тіла, визначення геометричних залежностей частин тіла, введення індексів статури на основі антропометричних вимірювань. Незважаючи на такий різний підхід, вчені намагалися зрозуміти, виміряти і класифікувати все різноманіття зовнішніх фрорм тіла. Окрім цього, тіло людини як біологічна система взаємодіє 3 навколишнім середовищем та постійно змінюється в часі й просторі, тому доцільно розглядати таке поняття, як «просторова організація тіла людини». Вона характеризується біогеометричним профілем по стави, формою статури, пропорціями і типом конституції, топографрією сил різних м'язових груп, використовується як характеристика фізичного розвитку здоров'я людини, реалізації людиною свого рухового потенціалу. Накопичений досвід розуміння поняття просторової організації тіла людини методичнихособливостейї̈формування потребує систематизації та відокремлення концептуальних положень.

2. Теоретико-методологічна основа концепції формування просторової організації тіла людини включає підходи загальнонаукового рівня методології та конкретно-наукового рівня, термінологічний апарат, інструментарій оцінювання та програмні продукти інфрормаційного супроводу моніторингу просторової організації тіла людини в процесі занять ффізичними вправами, здоров'ясормуючі та здоров'якорегуючі технології.

3. Здоров'яфрормуючі технології в процесі фрізичного виховання ді- тей молодшого шкільного віку реалізуються для фрормування просторової організації їхнього тіла, покращення рівня фрізичного стану, рухової активності, мотивації до систематичних занять фрізичними вправами, передбачають три етапи впровадження. До основних складових компонентів технологій належать: адаптаційний, операційно-діяльнісний, аксіологічний, гносеологічний, контрольний компоненти, зміст яких визначається відповідно до циклів навчання в початковій школі та в основу яких покладено особливості перебігу процесів адаптації дітей до умов навчання в школі, процесів їхнього фрізичного розвитку та становлення фрункціональних систем організму, поетапне формування просторової організації тіла дітей, фрізичної підготовленості, мотивації. Обов'язковою складовою впровадження здоров'яформуючих технологій є побудована система педагогічного контролю за адаптаційним, медико-біологічним, когнітивним, діяльнісно-поведінковим та аксіологічним критеріями.

4. Технологія просрілактики та корекції нефріксованих порушень ОРА у дітей старшого дошкільного віку засобами фрізичної реабілітації в умовах закладів дошкільної освіти охоплює мету, завдання, принципи, донозологічну діагностику, інфрормаційно-методичний, корекційно-профрілактичний, критерійно-оцінювальний компоненти, три етапи, варіативний і базовий компоненти з використанням теоретичних занять, ранкову гігієнічну гімнастику, заняття лікувальною гімнастикою із застосуванням фрітболгімнастики, елементи аквафітнесу, фрізкультхвилинки, масаж й електростимуляцію з біологічним зворотним зв'язком, попередній, оперативний, етапний контроль, інформаційноаналітичну систему «Posture control database 1,0», призначену для створення бази даних показників біогеометричного профрілю постави дітей 5-6 років, а також підвищення рівня теоретичних знань і практичних навичок вихователів закладів дошкільної освіти та батьків із питань контролю за поставою дітей, а також критерії есрективності. 
Перспективи подальшого дослідження полягають у практичному впровадженні розроблених теоретичних положень для контингенту осіб різного віку та статі.

Конфлікт інтересів. Автори заявляють, що відсутній будь-який конфрлікт інтересів.

\section{ЛIТЕРАТУРА}

1. Акчурин БГ. Телесность как проявление человеческого потенциала. Социально гуманитарные знания. 2004;2:317.

2. Альошина Al. Профрілактика й корекція функціональних порушень опорно-рухового апарату дошкільнят, школярів та студентської молоді у процесі фізичного виховання. Луцьк 2015. 356 c.

3. Бугуева НА. Телесность человека как социокультурный феномен. [Электронный ресурс]. Режим доступа: https://cyberleninka.ru/ article/v/telesnost-cheloveka-kak-sotsiokulturnyyfenomen

4. Быховская ИМ. «Homo somatikos»: ак сиология человеческого тела. Москва, 2000. c. 4,5 .

5. Визитей НН. Физическая культура личности (проблема человеческой телесности: мето дологические, социально-философские, педагогические аспекты). Кишинев, 1989. с. 4-45.

6. Выготский ЛС. Избранные психологические исследования. Москва: АПН РСФСР, 1956 с. 1-36, 453-503.

7. Гончарова НМ. Здоров'ясрормуючі технології у процесі фрізичного виховання дітей мо лодшого шкільного віку [монографія]. Луцьк: Вежа-Друк; 2018. 336 с

8. Дарвин ЧР. 0 выражении эмоций у человека и животных: пер. с англ. Санкт-Петербург: Питер, 2013. 315 с

9. Дмитриев СВ. Онтодидактика образовательных технологий на основе социокультур ной теории двигательных действий человека: Спорт, искусство, личностное развитие субъектов образования. Москва: Прометей, 2019 $446 \mathrm{c}$.

10. Кашуба ВА. Биомеханика осанки. Киев: Олимпийская лит.; 2003. 280 с.

11. Кашуба ВА, Адель Бен Жедду. Профилактика и коррекция нарушений пространственной организации тела человека в процессе физического воспитания. Киев: Знання України, 2005. 158 с.

12. Кашуба ВА, Бондарь ЕМ, Гончарова НH Носова НЛ. Формирование моторики человека в процессе онтогенеза. Луцьк: Вежа-Друк 2016. 232 c.

13. Кашуба В, Лопацький С. Теоретикопрактичні аспекти моніторингу просторово організації тіла людини. Івано-Франківськ: Видавець Кушнир Г.М., 2018. 232 с.

14. Кашуба В, Попадюха Ю. Біомеханіка просторової організації тіла людини: сучасн методи та засоби діагностики і відновлення по рушень. Київ: Центр учбової літератури, 2018. 768 c.

15. Кашуба В, Бибик Р, Носова Н. Контрол состояния пространственной организации тела человека в процессе физического воспитания история вопроса, состояние, пути решения Молодіжний науковий вісник Волинського нац. ун-ту ім. Л. Українки. Фізичне виховання і спорт. 2012;7:10-9.
16. Кашуба В, Гончарова Н, Ткачева А. Диагностика осанки человека: история и со временное состояние. Молодіжний науковий вісник Східноєвропейського національного університету імені Лесі Українки. 2016;21:9-14.

17. Кашуба ВО, Носова НЛ, Коломієць ТВ, Бондар ОМ, Соботюк СА, Лісовський БП. Апробація карти скринінг-контролю біогео метричного профілю постави дітей дошкільного віку в процесі фізичної реабілітації. Вісник При карпатського університету. Серія: Фізична культура. 2019; 34:45-52

18. Лапутин АН, Кашуба ВА. Формировани массы и динамика гравитационных взаимодей ствий тела человека в онтогенезе. Київ: Знання, 1999. 202 с

19. Лапутин АН, Кашуба ВА. Кинетика тела человека Фізичне виховання, спорт і культура здоров'я у сучасному суспільстві. 2009;4:40-9.

20. Лапутін АМ, Кашуба ВО. Динамічна анатомія: Навчальна програма для вузів фізич ного виховання та спорту. Київ, Науковийсвіт 2000. 12 c.

21. Лапутін АM, Кашуба Во. Кінетика тіла людини: Навчальна програма для ВНЗ фізичного виховання та спорту. Київ: Науковий світ, 2003. 13 c

22. Лапутин АН, Кашуба ВА, Сергиенко КН. Технология контроля двигательной функции стопы школьников в процессе фризического воспитания. Методическое пособие для студентов II курса факультета спортивной медици ны и физической реабилитации Киев: НУФВСУ, 2003. 65 c.

23. Литвина ДА, Остроухова ПВ. Дискурсивне регулирование женской телесности в социальных сетях: между худобой и анорексией. Журнал исследований социальной по литики. 2015;13(1):33-48. [Электронный ре сурс]. Режим доступа. https://jsps.hse.ru/article/ view/3346

24. Літопис Національного університету фізичного виховання і спорту України (19302005). Київ: Олімпійська л-ра, 2005. 232 с.

25. Мартиросов ЭГ, Николаев ДВ, Рудев СГ. Технологии и методы определения состава тела человека Москва: Наука; 2006. 248

26. Носова НЛ. Контроль просторово організації тіла школярів у процесі фрізичного виховання [авторесерат]. Київ: НУФВСУ; 2008. $19 \mathrm{c}$.

27. Носова Н, Коломієць Т, Маслова 0 . нсформаційно-аналітична система «Posture control database 1,0» - базисна основа тех нології контролю за станом опорно-рухово го апарату дітей 5-6 років 3 порушенням постави. Молодіжний науковий вісник Східно ввропейського нац. ун-ту ім. Лесі Українки. Фізичне виховання і спорт. 2018:32:140-52.

28. Орлова ЗН. Понятие «культура»: акси ологический аспект. Вестник Нижегородского университета им. Н. И. Лобачевского. Серия Социальные науки. 2007:2(7):158-63.

29. Резник ЮМ. Социокультурный подход как методология исследований. Вопросы социальной теории. 2008. Т. II, Вып. 1(2). с. 305-328.

30. Философский энциклопедический словарь. Москва: Инфра-М, 1999. с. 450.

31. Яковлев ЕВ, Яковлева НО. Педагогическая концепция: методологические аспекть построения. Москва: Гуманитар. изд. центр ВЛАДОС; 2006. 239 с

32. Hakman A, Andrieieva 0., Kashuba V. et al. Characteristics of biogeometric profile of posture and quality of life of students during the proces of physical education Journal of Physical Educa- tion and Sport 2020:20(1):79-85 doi:10.7752/ jpes.2020.01010

33. Imas YV, Dutchak MV, Andrieieva OV Kashuba V0, Kensytska IL, Sadovskyi 00. Modern approaches to the problem of values' formation of students' healthy lifestyle in the course of physical training. Physical education of students 2018;4:182-190.

34. Kashuba V, Andrieieva 0, Goncharova N, Kyrychenko V, Karp I, Lopatskyi S, Kolos M. Physical activity for prevention and correction of postural abnormalities in young women. Journal of Physical Education and Sport. 2019;19(St.2):500 6. doi:10.7752/jpes.2019.s2073

35. Kashuba V, Futornyi S, Andrieieva 0 Goncharova N, Carp I., Bondar 0, Nosova N. Optimization of the processes of adaptation to the conditions of study at school as a component of health forming activities of primary school age children. Journal of Physical Education and Sport. 2018;18(St.4):2515-21. doi:10.7752/ jpes.2018.04377

36. Kashuba V, Kolos M, Rudnytskyi 0 Yaremenko V, Shandrygos V, Dudko M, Andrie ieva 0 . Modern approaches to improving body constitution of female students within physical education classes. Journal of Physical Education and Sport.2017;17(4):2472-6. doi:10.7752/ jpes.2017.04277

37. Kashuba V, Savliuk S, Vypasniak I, Yavorskyy A, Kindrat P, Grygus I, Vakoliuk A, Panchuk I Hagner-Derengowska M. Differentiated approach for improving the physical condition of children with visual impairment during physical education. Journal of Physical Education and Sport 2020;20(St. 2):958-65. doi:10.7752/jpes.2020. s2133

38. Kashuba V, Tomilina Yu, Byshevets N Khrypko I, Stepanenko 0, Grygus I, Smoleńska O, Savliuk S. Impact of Pilates on the Intensity of Pain in the Spine of Women of the First Mature age. Teorîa ta Metodika Fìzičnogo Vihovannâ. 2020;20(1):12-17. https://doi.org/10.17309/tmfv 2020.1.02

39. Tkachova A, Dutchak M, Kashuba V Goncharova N, Lytvynenko Y, Vako I, Kolos M Lopatskyi S. Practical implementation of differentiated approach to developing water aerobic classes for early adulthood women with differen types of body build Journal of Physical Education and Sport. 2020;20(St. 1);456-60. https://doi. org/10.7752/jpes.2020.s1067

\section{LITERATURE}

1. Akchurin BG. Physicality as a manifestation of human potential. Socio-humanitarian knowledge. 2004;2:317.

2. Alioshyna Al. Prevention and correction of the locomotorium functional disorders in preschoolers, schoolchildren and students in the process of physical education. Lutsk; 2015. 356 p.

3. Bugueva NA. Human physicality as a sociocultural phenomenon. [Electronic resource] Access mode: https://cyberleninka.ru/article/v/ telesnost-cheloveka-kak-sotsiokulturnyy-fenomen

4. Bykhovskaya IM. «Homo somatikos»: hu man body axiology. Moscow, 2000. p. 4, 5 .

5. Vizitey NN. Physical culture of the individual (the problem of human corporeality: metho dological, socio-philosophical, pedagogical aspects). Kishinev, 1989. p. 4-45.

6. Vygotsky LS. Selected psychological research. Moscow: APN RSFSR, 1956. p. 1-36, 453 503. 
7. Honcharova NM. Health-forming technologies in the process of physical education of junior school children [monograph]. Lutsk: VezhaDruk; 2018. 336 p.

8. Darwin Ch. On the expression of emotions in humans and animals: trans. from English. Saint Petersburg: Piter, 2013. 315 p

9. Dmitriev SV. Ontodidactics of educationa technologies based on the socio-cultural theory of human motor actions: Sport, art, persona development of subjects of education. Moscow: Prometey, 2019. 446 p.

10. Kashuba VA. Posture biomechanics. Kiev: Olimpiyskaya literatura; 2003. 280 p.

11. Kashuba VA, Adele Ben Jeddu. Prevention and correction of disorders of the human body spatial organization in the process of physical education. Kiev: Znannia Ukrainy, 2005. 158 p.

12. Kashuba VA, Bondar EM, Goncharova NN Nosova NL. Formation of human motility in the process of ontogenesis. Lutsk: Vezha-Druk, 2016. $232 \mathrm{p}$.

13. Kashuba V, Lopatskyi S. Theoreticopractical aspects of monitoring human body spatial organization. Ivano-Frankivsk: Vydavets Kushnir G.M., 2018. 232 p.

14. Kashuba V, Popadiukha Y. Biomechanics of human body spatial organization: modern methods and means of diagnostics and repair of damage. Kiev: Tsentr uchbovoi literatury, 2018. $768 \mathrm{p}$.

15. Kashuba V, Bibik R, Nosova N. Contro of the state of human body spatial organization in the process of physical education: history of the issue, state, solutions. Molodizhnyi naukovy visnyk Volynskoho natsionalnoho universytetu im. L. Ukrainky. 2012;7:10-9.

16. Kashuba V, Goncharova N, Tkacheva A. Diagnostics of human posture: history and current state. Molodizhnyi naukovyi visnyk Skhidnoievropeyskoho universytetu im. Lesi Ukrainky. 2016;21:9-14.

17. Kashuba VO, Nosova NL, Kolomiiets TV, Bondar OM, Sobotiuk SA, Lisovskyi BP. Approbation of the screening-control map of the biogeometric profile of preschoolers' posture in the process of physical rehabilitation. Visnyk Prykarpatskoho universytetu. 2019; 34:45-52.
18. Laputin AN, Kashuba VA. Formation of mass and dynamics of human body gravitational interactions in ontogenesis. Kyiv: Znannia, 1999. $202 \mathrm{p}$

19. Laputin AN, Kashuba VA. Human body kinetics. Fizychne vykhovannia, sport i kultura zdorovia u suchasnomu suspilstvi. 2009;4:40-9.

20. Laputin AM, Kashuba VO. Dynamic anatomy: Curriculum for physical education and sport institutions. Kyiv, Naukovyi svit, 2000.12 p.

21. Laputin AN, Kashuba V0. Human body kinetics: Curriculum for physical education and sport institutions. Kyiv, Naukovyi svit, 2003. 13 p.

22. Laputin AN, Kashuba VA, Sergienko KN. Technology for controlling the motor function of the foot of schoolchildren in the process of physical education. Methodological manual for second-yea students of the Faculty of Sports Medicine and Physical Rehabilitation Kiev: NUPESU, 2003. 65 p.

23. Litvina DA, Ostroukhova PV. Discursive regulation of female physicality on social networks: between thinness and anorexia. Zhurna issledovaniy sotsialnoy politiki. 2015;13(1):33-48. [Electronic resource]. Access mode. https://jsps hse.ru/article/view/3346

24. Chronicle of the National University of Physical Education and Sport of Ukraine (19302005). Kyiv: Olimpiyska literatura, 2005. 232 p.

25. Martirosov EG, Nikolaev DV, Rudnev SG. Technologies and methods for determining the human body composition. Moscow: Nauka; 2006. $248 \mathrm{p}$.

26. Nosova NL. Control of schoolchildren body spatial organization in the process of physica education [abstract]. Kyiv: NUPESU; 2008. 19 p.

27. Nosova N, Kolomiiets T, Maslova O. Information-analytical system «Posture control database 1.0» - the basic basis of technology for monitoring the condition of the locomoto rium of children 5-6 years with postural disorders Molodizhnyi naukovyi visnyk Skhidnoievropeys koho universytetu im. Lesi Ukrainky. 2018;32:140 52.

28. Orlova ZN. The concept of "culture»: axiological aspect. Vestnik Nizhegorodskogo universiteta im. N. I. Lobachevskogo. 2007;2(7):15863.

\section{ІНФОРМАЦІЯ ПРО АВТОРІВ}

Кашуба Віталій Олександрович orcid.org/0000-0001-6669-738X, kashubavo@gmail.com Гончарова Наталія Миколаївна https:orcid.org/0000-0002-3000-9044, nataliinfiz@gmail.com Носова Наталія Леонідівна https://orcid.org/0000-0002-3226-0435, nnosova75@gmail.com Національний університет фізичного виховання і спорту України, 03150, Київ, вул. Фізкультури, 1.

\section{INFORMATION ABOUT THE AUTHORS}

Kashuba Vitalii orcid.org/0000-0001-6669-738X, kashubavo@gmail.com Goncharova Nataliia https:orcid.org/0000-0002-3000-9044, nataliinfiz@gmail.com Nosova Nataliya https://orcid.org/0000-0002-3226-0435, nnosova75@gmail.com National University of Ukraine on Physical Education and Sport, 03150, Kyiv, Fizkul'tury str., 1.
29. Reznik YM. Sociocultural approach as a research methodology. Social theory issues. 2008. Vol. II, Iss. 1(2). p. 305-328.

30. Philosophical Encyclopedic Dictionary. Moscow: Infra-M, 1999. p. 450.

31. Yakovlev EV, Yakovleva NO. Pedagogical concept: methodological aspects of construction. Moscow: Gumanitarny izd. tsentr VLADOS; 2006. $239 \mathrm{p}$.

32. Hakman A, Andrieieva O., Kashuba V. et al. Characteristics of biogeometric profile of posture and quality of life of students during the process of physical education Journal of Physical Education and Sport 2020;20(1):79-85. doi:10.7752/ jpes.2020.01010

33. Imas YV, Dutchak MV, Andrieieva OV, Kashuba V0, Kensytska IL, Sadovskyi 00. Modern approaches to the problem of values' formation of students' healthy lifestyle in the course of physical training. Physical education of students. 2018;4:182-190

34. Kashuba V, Andrieieva O, Goncharova N, Kyrychenko V, Karp I, Lopatskyi S, Kolos M. Physical activity for prevention and correction of postural abnormalities in young women. Journal of Physical Education and Sport. 2019;19(St.2):5006. doi:10.7752/jpes.2019.s2073

35. Kashuba V, Futornyi S, Andrieieva 0, Goncharova N, Carp I., Bondar 0, Nosova N. Optimization of the processes of adaptation to the conditions of study at school as a component of health forming activities of primary schoolage children. Journal of Physical Education and Sport. 2018;18(St.4):2515-21. doi:10.7752/jpes. 2018.04377

36. Kashuba V, Kolos M, Rudnytskyi 0, Yaremenko V, Shandrygos V, Dudko M, Andrieieva 0 . Modern approaches to improving body constitution of female students within physical education classes. Journal of Physical Education and Sport.2017;17(4):2472-6. doi:10.7752/jpes. 2017.04277

37. Kashuba V, Savliuk S, Vypasniak I, Yavorskyy A, Kindrat P, Grygus I, Vakoliuk A, Panchuk I, Hagner-Derengowska M. Differentiated approach for improving the physical condition of children with visual impairment during physical education. Journal of Physical Education and Sport. 2020;20(St. 2):958-65. doi:10.7752/jpes.2020. s2133

38. Kashuba V, Tomilina Yu, Byshevets N, Khrypko I, Stepanenko O, Grygus I, Smoleńska O, Savliuk S. Impact of Pilates on the Intensity of Pain in the Spine of Women of the First Mature age. Teoriâ ta Metodika Fìzičnogo Vihovannâ. 2020;20(1):12-17. https://doi.org/10.17309/tmfv. 2020.1.02

39. Tkachova A, Dutchak M, Kashuba V, Goncharova N, Lytvynenko Y, Vako I, Kolos M, Lopatskyi S. Practical implementation of differentiated approach to developing water aerobics classes for early adulthood women with different types of body build Journal of Physical Education and Sport. 2020;20(St. 1);456-60. https://doi. org/10.7752/jpes.2020.s1067

Надійшла 18.03.2020 